\title{
The simulated climate of the Last Glacial Maximum and insights into the global marine carbon cycle
}

\author{
Pearse J. Buchanan ${ }^{1,2,3}$, Richard J. Matear ${ }^{2,3}$, Andrew Lenton ${ }^{2}$, Steven J. Phipps ${ }^{1}$, Zanna Chase ${ }^{1}$, and \\ David M. Etheridge ${ }^{4}$ \\ ${ }^{1}$ Institute for Marine and Antarctic Studies, University of Tasmania, Hobart, Tasmania, Australia \\ ${ }^{2}$ CSIRO Oceans and Atmosphere, CSIRO Marine Laboratories, G.P.O. Box 1538, Hobart, Tasmania, Australia \\ ${ }^{3}$ ARC Centre of Excellence in Climate System Science, University of Tasmania, Hobart, Australia \\ ${ }^{4}$ CSIRO Ocean and Atmosphere, Aspendale, Victoria, Australia
}

Correspondence to: Pearse J. Buchanan (pearse.buchanan@utas.edu.au)

Received: 1 July 2016 - Published in Clim. Past Discuss.: 11 July 2016

Revised: 21 November 2016 - Accepted: 27 November 2016 - Published: 22 December 2016

\begin{abstract}
The ocean's ability to store large quantities of carbon, combined with the millennial longevity over which this reservoir is overturned, has implicated the ocean as a key driver of glacial-interglacial climates. However, the combination of processes that cause an accumulation of carbon within the ocean during glacial periods is still under debate. Here we present simulations of the Last Glacial Maximum (LGM) using the CSIRO Mk3L-COAL (Carbon-OceanAtmosphere-Land) earth system model to test the contribution of physical and biogeochemical processes to ocean carbon storage. For the LGM simulation, we find a significant global cooling of the surface ocean $\left(3.2^{\circ} \mathrm{C}\right)$ and the expansion of both minimum and maximum sea ice cover broadly consistent with proxy reconstructions. The glacial ocean stores an additional $267 \mathrm{Pg} \mathrm{C}$ in the deep ocean relative to the pre-industrial (PI) simulation due to stronger Antarctic Bottom Water formation. However, $889 \mathrm{PgC}$ is lost from the upper ocean via equilibration with a lower atmospheric $\mathrm{CO}_{2}$ concentration and a global decrease in export production, causing a net loss of carbon relative to the PI ocean. The LGM deep ocean also experiences an oxygenation ( $>100 \mathrm{mmol} \mathrm{O}_{2} \mathrm{~m}^{-3}$ ) and deepening of the calcite saturation horizon (exceeds the ocean bottom) at odds with proxy reconstructions. With modifications to key biogeochemical processes, which include an increased export of organic matter due to a simulated release from iron limitation, a deepening of remineralisation and decreased inorganic carbon export driven by cooler temperatures, we find that the carbon content of the glacial ocean can be suffi-
\end{abstract}

ciently increased $(317 \mathrm{PgC})$ to explain the reduction in atmospheric and terrestrial carbon at the LGM (194 \pm 2 and $330 \pm 400 \mathrm{Pg} \mathrm{C}$, respectively). Assuming an LGM-PI difference of $95 \mathrm{ppm} p \mathrm{CO}_{2}$, we find that $55 \mathrm{ppm}$ can be attributed to the biological pump, $28 \mathrm{ppm}$ to circulation changes and the remaining $12 \mathrm{ppm}$ to solubility. The biogeochemical modifications also improve model-proxy agreement in export production, carbonate chemistry and dissolved oxygen fields. Thus, we find strong evidence that variations in the oceanic biological pump exert a primary control on the climate.

\section{Introduction}

The Late Pleistocene is characterised by a sawtooth-like cycling between cool glacial and warm interglacial states (Emiliani, 1966; Shackleton, 1967). Global temperatures and atmospheric $\mathrm{CO}_{2}$ are strongly correlated across these climate cycles with approximately $80-100$ ppm of change corresponding to global mean temperature variations of $3-4{ }^{\circ} \mathrm{C}$ (Grootes and Stuiver, 1997; Jouzel et al., 1987; Parrenin et al., 2013; Petit et al., 1999). This correlation was extended to causation by evidence that increases in atmospheric $\mathrm{CO}_{2}$ preceded decreases in global ice mass during glacial terminations (Sowers et al., 1991; Broecker and Henderson, 1998). The large potential of the ocean to store carbon, coupled with evidence that the terrestrial reservoir was diminished under glacial conditions (Shackleton, 1977), has implicated the ocean as the prime candidate for driving glacial- 
interglacial changes in atmospheric $\mathrm{CO}_{2}$ (Broecker, 1982; Skinner et al., 2015; Wilson et al., 2015). However, identifying the combination of mechanisms that drove a flux of carbon into the ocean during glacial periods remains a fundamental and largely unresolved problem.

If we first consider only physical changes, a net influx of $\mathrm{CO}_{2}$ caused by cooling is a feature of the glacial ocean. However, the increase in solubility attributed to cooling is partially offset by increased salinity due to a lower sea level (Siddall et al., 2003), so that the contribution of solubility changes is estimated at $\sim 13 \mathrm{ppm}$ of the total 80 100 ppm $\mathrm{CO}_{2}$ drawdown (Sigman and Boyle, 2000; Kohfeld and Ridgwell, 2009). Therefore, other physical changes associated with a glacial climate, notably changes to the largescale circulation and sea ice fields (Stephens and Keeling, 2000), may make a considerable contribution to carbon sequestration. Proxy evidence (Curry and Oppo, 2005; Duplessy et al., 1988; McManus et al., 2004; Oliver et al., 2010; Skinner et al., 2010) and model experiments (Brovkin et al., 2007; Hain et al., 2010; Menviel et al., 2012; Watson and Naveira Garabato, 2006) of the glacial climate have shown that a greater proportion of the deep ocean was dominated by southern source waters (see Adkins, 2013, for a review). The existence of this glacial-type circulation has been connected to an expanded sea ice field (Ferrari et al., 2014). An expansion of southern source waters throughout the deep ocean and an expanded sea ice field are now considered to be primary candidates for carbon sequestration during glacial climates (Adkins, 2013).

However, the most promising explanations of the glacial decline in atmospheric $\mathrm{CO}_{2}$ involve changes to ocean productivity in concert with reorganisations of the global overturning circulation (Hain et al., 2010; Gottschalk et al., 2016). An increased glacial productivity, first proposed by Broecker (1982) and explored by Archer et al. (2000) by increasing the global nutrient inventory, is now an established feature of the subantarctic zone due to enhanced aeolian deposition of iron (Martinez-Garcia et al., 2014). The Southern Ocean exerts a strong control on atmospheric $\mathrm{CO}_{2}$ through its direct connection with deep waters (Marinov et al., 2006), and enhanced productivity in this zone is thus a prime candidate for explaining a fraction of the glacial-interglacial $\mathrm{CO}_{2}$ difference.

In numerous other regions, however, productivity appears to have been reduced during glacial climates. The affected regions include waters south of the Antarctic Polar Front (Francois et al., 1997; Jaccard et al., 2013), the North Pacific (Crusius et al., 2004; Jaccard et al., 2005; Kohfeld and Chase, 2011; Ortiz et al., 2004), the tropical Indian Ocean (Singh et al., 2011) and the equatorial Pacific (Costa et al., 2016; Herguera, 2000; Loubere et al., 2007). A weaker export production in these regions would have offset a strengthened biological pump in the subantarctic, thereby weakening the ability of the ocean to store carbon during glacial conditions. Whether the strengthening of the biological pump in the glacial subantarctic was sufficient to increase the carbon content of the ocean despite losses in productivity in other regions therefore requires further testing.

This has led some authors to look for alternative biogeochemical mechanisms. A notable example is the application of temperature-dependent remineralisation to global fluxes of organics into the interior ocean. The positive relationship between microbial metabolism and temperature has been known for some time (Eppley, 1972), but it was only recently that this relationship was applied to a glacial setting. By prescribing a global cooling of $5{ }^{\circ} \mathrm{C}$, Matsumoto (2007) reduced atmospheric $\mathrm{CO}_{2}$ by $\sim 35 \mathrm{ppm}$. Further research has shown that even a slight deepening in the remineralisation profile can cause large changes in oceanic carbon content by reducing surface ocean inorganic carbon concentrations, which in turn strengthens the air-sea influx of carbon (Menviel et al., 2012).

Another biogeochemical mechanism that is proposed to increase oceanic carbon storage is an altered calcium carbonate to organic carbon $\left(\mathrm{CaCO}_{3}: \mathrm{C}_{\mathrm{org}}\right)$ export production ratio (Sigman et al., 1998; Archer et al., 2000). A global decrease in the $\mathrm{CaCO}_{3}: \mathrm{C}_{\text {org }}$ ratio would enhance carbon storage by reducing the $p \mathrm{CO}_{2}$ of surface waters (see Sigman and Boyle, 2000, for a review). A decrease in $\mathrm{CaCO}_{3}$ production could be caused by cooling (Stoll et al., 2002) and/or an increase in silicate delivery to the lower-latitude oceans that simulated organic carbon production (Matsumoto et al., 2002).

Numerous physical and biogeochemical changes have been associated with a glacial ocean and all have been identified in some respect as important drivers of glacialinterglacial climate cycles. Now, recent insights into the distributions of dissolved oxygen (Jaccard et al., 2014) and carbonate species (Yu et al., 2014) at the Last Glacial Maximum (LGM; 21000 years BCE) provide new constraints to identify which combination of physical and biogeochemical changes could have realistically sequestered carbon within the ocean at this time. Here, we use an earth system model with attached biogeochemistry, CSIRO Mk3L-COAL (Carbon-Ocean-Atmosphere-Land), to test current theories against these new insights. Using our simulated LGM ocean state, we quantify the contribution of physical and biogeochemical changes to the estimated increased of $520 \pm 400 \mathrm{Pg}$ of carbon within the oceanic reservoir at the LGM (Ciais et al., 2011) and demonstrate the importance of marine biogeochemistry to global climate.

\section{Model and experiments}

The model simulations were performed using the CSIRO Mk3L climate system model version 1.2 (Phipps et al., 2011, 2012), which includes components that describe the atmosphere, land, sea ice and ocean. The horizontal resolution of the atmosphere, land and sea ice models is $5.6^{\circ} \times 3.2^{\circ}$ in the longitudinal and latitudinal dimensions, respectively, with 18 
vertical levels. The ocean model has a horizontal resolution of $2.8^{\circ} \times 1.6^{\circ}$ with 21 vertical levels. For this study, we conduct simulations using both the full climate system model and the stand-alone ocean model.

Two fully coupled model experiments were undertaken to simulate the pre-industrial (Cpl-PI) and Last Glacial Maximum (Cpl-LGM) climates. The Cpl-PI climate was obtained by forcing the model with an atmospheric $\mathrm{CO}_{2}$ concentration of $280 \mathrm{ppm}$ and by prescribing $1950 \mathrm{CE}$ values for the orbital parameters. This experiment was integrated for a total of 10000 years (Phipps et al., 2013). The Cpl-LGM simulation followed the protocol developed by Phase III of the Palaeoclimate Modelling Intercomparison Project (PMIP3), with the exception that no changes were made to terrestrial topography, oceanic bathymetry or the positions of the coastlines. The closure of important oceanic connections due to sea level loss, such as the Bering Strait, was not considered. The atmospheric $\mathrm{CO}_{2}$ equivalent concentration was set to $167 \mathrm{ppm}$, providing a radiative forcing equivalent to the specified reductions in the atmospheric concentrations of $\mathrm{CO}_{2}$, $\mathrm{CH}_{4}$ and $\mathrm{N}_{2} \mathrm{O}$ from $280 \mathrm{ppm}, 760 \mathrm{ppb}$ and $270 \mathrm{ppb}$ for preindustrial simulations to $185 \mathrm{ppm}, 350 \mathrm{ppb}$ and $200 \mathrm{ppb}$ for LGM simulations. The orbital parameters were set to values for 21000 years BP. The Cpl-LGM simulation was initialised from the state of the Cpl-PI simulation at the end of model year 100. The model was then integrated for a total of 3900 model years, until it had reached quasi-equilibrium. Over this integration the ocean experienced an increase in salinity by 0.5 PSU due to increased evaporation, which reflected the coupling between a cooler, drier atmosphere and the ocean.

With the climate state provided by the Cpl-LGM experiment, nine additional ocean biogeochemical simulations were made with different physical and biogeochemical conditions to explore the effect on the carbon cycle (Table 1). These experiments utilised Mk3L-COAL, an enhanced version of the Mk3L climate system model which includes biogeochemical modules embedded within the ocean, atmosphere and terrestrial models. All experiments were forced by key boundary conditions (wind stresses, temperature, salinity, incident radiation, sea ice), which were obtained as monthly averages over the final 50 years of the fully coupled model experiments. The heat and freshwater fluxes into the ocean were determined by relaxing the sea surface temperature (SST) and sea surface salinity (SSS) towards the prescribed fields using a 20-day timescale. An additional 0.5 PSU was added to the salinity field of the LGM experiments to ensure that the ocean was 1 PSU more saline than the PI. For a description of the ocean biogeochemistry the reader is directed towards Appendix A of Matear and Lenton (2014) and the experiments of Duteil et al. (2012).

First, five experiments were conducted to explore how the physics of a glacial ocean affected carbon content. Two experiments, O-PI and O-LGM, were completed under standard PI and LGM conditions. These standard experiments were compared with three additional experiments that together were used to discern how changes in solubility, sea ice and circulation between the PI and LGM climates affected carbon. One of these experiments, $\mathrm{O}-\mathrm{PI}_{\mathrm{CO}_{2}}^{\mathrm{LGM}}$, involved a standard PI simulation with prescribed atmospheric $p \mathrm{CO}_{2}$ concentrations of the LGM (185 ppm). This allowed direct comparison between experiments O-LGM and $\mathrm{O}-\mathrm{PI}_{\mathrm{CO}_{2}}^{\mathrm{LGM}}$ to determine how global physical changes affected carbon storage. To separate the effects of an expanded sea ice field, solubility changes and circulation changes at the LGM, another two PI experiments, $\mathrm{O}-\mathrm{PI}_{\text {ice }}^{\mathrm{LGM}}$ and $\mathrm{O}-\mathrm{PI}_{\text {sol }}^{\mathrm{LGM}}$, were completed. These experiments were forced by PI physics, such that a PI circulation was present, but the biogeochemical model responded to the sea ice field and sea surface conditions (temperature and salinity) of the LGM under an atmospheric $p \mathrm{CO}_{2}$ of $185 \mathrm{ppm}$. An atmospheric $p \mathrm{CO}_{2}$ of $185 \mathrm{ppm}$ was chosen for direct comparison with experiment $\mathrm{O}-\mathrm{PI}_{\mathrm{CO}_{2}}^{\mathrm{LGM}}$.

Second, four experiments $\left(\mathrm{O}-\mathrm{LGM}_{\text {poc }}^{\mathrm{BGC}}\right.$, O-LGM $\mathrm{LGm}_{\mathrm{rem}}^{\mathrm{BGC}}$ O$\mathrm{LGM}_{\text {pic }}^{\mathrm{BGC}}$ and O-LGM $\mathrm{O}$ all ) represented LGM experiments in which the equations controlling biogeochemical cycling were altered. It should be made clear that these experiments did not explicitly simulate the biogeochemical changes caused by an altered climate in any mechanistic sense. However, the prescription of the following changes allowed us to undertake a theoretical investigation into their capacity to sequester carbon at the LGM. The experiments were as follows:

O-LGM poc . The scaling factor $\left(S_{\text {npp }}^{\mathrm{O}}\right)$ was increased by a factor of 10 (Eq. 1) to increase the export of particulate organic carbon (POC) from the surface ocean and therefore strengthen the biological carbon pump. Increasing POC export in the LGM ocean was motivated by an enhanced delivery of iron to the surface ocean via aeolian dust at the LGM (Martin, 1990; Martinez-Garcia et al., 2014).

$\mathrm{POC}=S_{\mathrm{npp}}^{\mathrm{O}} \cdot V_{\max } \cdot \min \left(\frac{\left[\mathrm{PO}_{4}\right]}{\left[\mathrm{PO}_{4}\right]+P_{k}}, F(I)\right)$,

where $V_{\max }$ is the temperature-dependent maximum growth of phytoplankton (Eppley, 1972); $P_{k}$ is the halfsaturation constant for nutrient-limited growth, set to $0.1 \mathrm{mmol} \mathrm{PO}_{4} \mathrm{~m}^{-3}$; and $F(I)$ is the productivity versus irradiance equation for determining light-limited growth (Clementson et al., 1998).

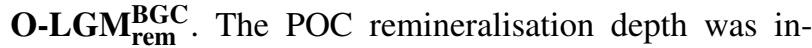
creased by changing the power law exponent $(b)$ in Eq. (2) from -0.9 to -0.7 , which replicated a bulk shift of POC from the upper to the deep ocean. The motivation for increasing the amount of POC that reaches deeper levels is the expectation that a cooler ocean would reduce the rate of bacterial remineralisation in the upper ocean (Rivkin and Legendre, 2001; Matsumoto, 2007). This change increased the simulated POC that reaches the $1000 \mathrm{~m}$ depth level from 12.5 to $20 \%$.

$\operatorname{Remin}(z)=\min \left(1,\left(\frac{z}{100}\right)^{b}\right)$ 
Table 1. Summary of modelling experiments performed. An O before a model name denotes that it was an ocean-only simulation. BGC refers to biogeochemistry.

\begin{tabular}{|c|c|c|c|c|}
\hline Experiment & Model & $\begin{array}{l}\text { Greenhouse gas } \\
\text { forcing }\left(\mathrm{CO}_{2} \mathrm{e}\right)^{\mathrm{a}}\end{array}$ & $\begin{array}{l}\text { Orbital } \\
\text { parameters }\end{array}$ & Comment \\
\hline Cpl-PI & Coupled & 280 & $0 \mathrm{kaBP}$ & Unmodified BGC \\
\hline Cpl-LGM & Coupled & 167 & $21 \mathrm{kaBP}$ & Unmodified BGC \\
\hline Experiment & Model & $\begin{array}{l}\text { Atmospheric } \\
\mathrm{CO}_{2}(\mathrm{ppm})\end{array}$ & $\begin{array}{l}\text { Climate } \\
\text { state }\end{array}$ & Comment \\
\hline O-PI & Ocean & 280 & PI & Unmodified BGC \\
\hline O-LGM & Ocean & 185 & LGM & Unmodified BGC \\
\hline $\mathrm{O}-\mathrm{PI}_{\mathrm{CO}}^{\mathrm{LGM}}$ & Ocean & 185 & PI & Unmodified BGC \\
\hline O-PI LGM & Ocean & 185 & PI & Unmodified BGC/LGM sea ice \\
\hline $\mathrm{O}-\mathrm{PI}_{\mathrm{sol}}^{\mathrm{LG}}$ & Ocean & 185 & PI & Unmodified BGC/LGM SST and SSS \\
\hline O-LGM ${ }_{\mathrm{poc}}^{\mathrm{BgC}}$ & Ocean & 185 & LGM & $10 \times$ potential export production \\
\hline $\mathrm{O}-\mathrm{LGM}_{\mathrm{rem}}^{\mathrm{BGC}}$ & Ocean & 185 & LGM & Increased depth of remineralisation ${ }^{\mathrm{b}}$ \\
\hline O-LGM pic $_{\text {Bic }}^{\text {BGC }}$ & Ocean & 185 & LGM & No particulate inorganic carbon export \\
\hline $\mathrm{O}-\mathrm{LGM}_{\mathrm{all}}^{\mathrm{BGC}}$ & Ocean & 185 & LGM & BGC modifications of O-LGM $\mathrm{Loc}_{\text {poc }}^{\mathrm{BGC}}$ O-LGM $\mathrm{LGm}_{\mathrm{rem}}^{\mathrm{BGC}}$ and O-LGM $\mathrm{Lic}^{\mathrm{BGC}}$ \\
\hline
\end{tabular}

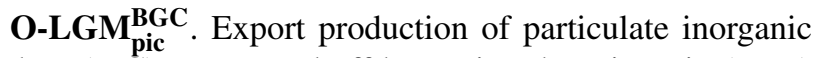
carbon $(\mathrm{PIC})$ was turned off by setting the rain ratio $\left(R_{\mathrm{PIC}}\right)$ of PIC : POC to zero in Eq. (3). The motivation for reducing PIC export in the glacial ocean is related to the positive linear relationship between calcification and temperature (Stoll et al., 2002) and an increased silicate supply to lower latitudes that potentially favoured non-calcifying producers (Matsumoto et al., 2002).

$\mathrm{PIC}=\mathrm{POC} \cdot R_{\mathrm{PIC}}$

O-LGM $\mathbf{L a l l}_{\text {all }}^{\mathbf{B G C}}$. All three modifications to ocean biogeochemistry were employed. All ocean-only simulations were integrated for 10000 years to ensure that the ocean carbon cycle reached a steady state.

To assess whether the behaviour of the biogeochemical tracers within the coupled model differed from those in the ocean-only model, we ran the coupled model with online ocean biogeochemistry for a further 1000 years using the steady-state biogeochemical fields from the ocean-only experiments. This assessment was made using both the PI and LGM climates. For key diagnostics, such as the meridional overturning circulation, ocean carbon content and global export production, the behaviour of the ocean-only simulation differed by less than $1 \%$ from the coupled simulations. Given the computational speed of the ocean-only model, these experiments provide an ideal platform to test the sensitivity of the ocean biogeochemical fields to the parameterisations used in the biogeochemical model.

\section{Results and discussion}

In the following, we first discuss the simulated physical changes to the ocean observed between the Cpl-PI and Cpl-
LGM simulations. Second, we discuss how the ocean biogeochemical fields differed between the O-PI and O-LGM simulations, which were forced with the output of the coupled simulations. Finally, we explore how modifying biogeochemical parameterisations alters the biogeochemistry, including changes to carbon storage, export production, carbonate chemistry and dissolved oxygen.

\subsection{LGM climate: physical fields}

\subsubsection{Sea surface temperature (SST)}

The simulated change in SST between the Cpl-PI and the Cpl-LGM simulations shows a similar magnitude and spatial structure to proxy reconstructions and prior modelling studies, with the greatest cooling in the equatorial oceans, high latitudes and eastern boundary currents and the least cooling in the subtropics and western boundary current regions (Fig. 1; Table 2). The global SST mean of the Cpl-LGM was $3.2^{\circ} \mathrm{C}$ cooler than the Cpl-PI. This change falls within the range of estimates $\left(\sim 2-4^{\circ} \mathrm{C}\right)$ produced by other climate models (Alder and Hostetler, 2015; Annan and Hargreaves, 2013; Braconnot et al., 2007) but sits towards the cooler limits of previous multiproxy SST reconstructions that estimate a change of $2 \pm 1.8^{\circ} \mathrm{C}$ (Ballantyne et al., 2005; Waelbroeck et al., 2009). However, a recent reanalysis of the proxy data presented by Waelbroeck et al. (2009) showed past estimates may have underestimated cooling by as much as $50 \%$ (Ho and Laepple, 2015). This finding reconciles some disagreement between climate models and palaeoproxies and places our simulated cooling of $3.2^{\circ} \mathrm{C}$ well within the bounds of uncertainty in reconstructions.

Regionally, the greatest cooling took place in the high latitudes and in the equatorial Pacific, where temperatures were 
Table 2. Changes in sea surface temperature (SST), sea ice extent and large-scale circulation between the LGM and PI simulations. SST changes are compared with proxy reconstructions of SST generated by Waelbroeck et al. (2009) and Ho and Laepple (2015), who use different proxies for their reconstructions to produce the differences depicted here and discussed in the text. The values of AABW and NADW formation provided by the models from the Palaeoclimate Modelling Intercomparison Project Phase II (PMIP2) are presented by Otto-Bliesner et al. (2007). The transport rate of the Antarctic Circumpolar Current (ACC) for the PMIP2 models is presented by LynchStieglitz et al. (2016). The estimates of NADW production provided by the PMIP3 models were taken from Muglia and Schmittner (2015).

\begin{tabular}{|c|c|c|c|c|c|}
\hline & & \multicolumn{4}{|c|}{$\Delta \mathrm{SST}\left({ }^{\circ} \mathrm{C}\right)$} \\
\hline & & $15^{\circ} \mathrm{S}-15^{\circ} \mathrm{N}$ & $30^{\circ} \mathrm{S}-30^{\circ} \mathrm{N}$ & $60^{\circ} \mathrm{S}-60^{\circ} \mathrm{N}$ & $90^{\circ} \mathrm{S}-90^{\circ} \mathrm{N}$ \\
\hline \multirow[t]{2}{*}{ Simulated } & Global & -3.3 & -3.2 & -3.9 & -3.2 \\
\hline & Atlantic & -3.6 & -3.4 & -3.9 & -3.3 \\
\hline \multirow[t]{2}{*}{ Waelbroeck et al. (2009) } & Global & $-1.7 \pm 1.0$ & $-1.5 \pm 1.2$ & $-1.9 \pm 1.7$ & $-1.9 \pm 1.8$ \\
\hline & Atlantic & $-2.9 \pm 1.3$ & $-2.3 \pm 1.5$ & $-2.6 \pm 2.0$ & $-2.4 \pm 2.2$ \\
\hline \multirow[t]{3}{*}{ Ho and Laepple (2015) } & Global & & -5.1 to $-2.17 \pm 1.43$ & & -12.52 to $-2.17 \pm 1.43$ \\
\hline & & \multicolumn{4}{|c|}{ Sea ice extent $\left(10^{6} \mathrm{~km}^{2}\right)$} \\
\hline & & SH maximum & SH minimum & NH maximum & NH minimum \\
\hline \multirow[t]{2}{*}{ Simulated } & PI & 20.8 & 4.12 & 15.0 & 9.73 \\
\hline & LGM & 46.3 & 13.3 & 36.6 & 19.9 \\
\hline Gloersen et al. (1993) & PI & 19 & 3.5 & 16 & 9 \\
\hline \multirow[t]{3}{*}{ Gersonde et al. (2005) } & LGM & 39 & & & \\
\hline & & \multicolumn{3}{|c|}{ Overturning metrics } & \\
\hline & & $\mathrm{AABW}^{\mathrm{a}}(\mathrm{Sv})$ & $\mathrm{AMOC}^{\mathrm{b}}(\mathrm{Sv})$ & $\mathrm{ACC}$ transport $^{\mathrm{c}}(\mathrm{Sv})$ & \\
\hline \multirow[t]{2}{*}{ Simulated } & PI & 10.3 & 15.6 & 140 & \\
\hline & LGM & 20.2 & 11.4 & 309 & \\
\hline \multirow[t]{2}{*}{ PMIP2 models } & PI & $10.4-16.2$ & $18.6-19.4$ & $50-300$ & \\
\hline & LGM & $19.6-40.0$ & $13.9-30.7$ & $80-350$ & \\
\hline \multirow[t]{2}{*}{ PMIP3 models } & PI & & $12.6-23.0$ & & \\
\hline & LGM & & $21.4-31.6$ & & \\
\hline
\end{tabular}

a The rate of Antarctic Bottom Water (AABW) formation is calculated as the annual average of the most negative rate of overturning (Sv) in the Southern Ocean south of $60^{\circ} \mathrm{S}$ and deeper than $500 \mathrm{~m}$. ${ }^{\mathrm{b}}$ The rate of overturning in the Atlantic Meridional Overturning Circulation (AMOC) is calculated as the annual average of the most positive rate of overturning (Sv) in the North Atlantic Ocean north of $0^{\circ}$ and deeper than $500 \mathrm{~m} .{ }^{\mathrm{c}}$ The transport of water by the Antarctic Circumpolar Current (ACC) is calculated as the annual and zonal average of the barotropic stream function at $60^{\circ} \mathrm{S}$.

in excess of $4^{\circ} \mathrm{C}$ cooler than the Cpl-PI climate. Meanwhile, the Western Pacific Warm Pool, subtropical gyres and western boundary currents cooled less $\left(0.5-3.0^{\circ} \mathrm{C}\right)$. Again, proxy (Waelbroeck et al., 2009) and climate modelling (Annan and Hargreaves, 2013) are consistent with both the magnitude and spatial pattern of cooling. A notable example of modeldata agreement is in the Pacific sector of the Southern Ocean, where SSTs were up to and in excess of $4{ }^{\circ} \mathrm{C}$ cooler at the LGM (Benz et al., 2016). Enhanced cooling in the high latitudes and in the eastern boundary currents generated strong zonal and meridional temperature gradients relative to $\mathrm{Cpl}-$ PI SST. There is a consistent regional pattern to SST cooling in the LGM emerging from proxy and model simulations (Annan and Hargreaves, 2013; Braconnot et al., 2007) that is broadly consistent with our simulated cooling.

Where there is still large uncertainty in SST change at the LGM is in the tropical ocean (see Annan and Hargreaves, 2015 , for a review). The Cpl-LGM cooling of $3.3^{\circ} \mathrm{C}$ across the tropical ocean $\left(15^{\circ} \mathrm{S}-15^{\circ} \mathrm{N}\right)$ is greater than other simula- tions (Annan and Hargreaves, 2013; Braconnot et al., 2007) but falls well within the -5.1 to $-2.17^{\circ} \mathrm{C}$ estimated by Ho and Laepple (2015). Regionally, climate models (OttoBliesner et al., 2009) and proxies (Waelbroeck et al., 2009) agree that cooling in the tropical Atlantic Ocean probably exceeded cooling in the tropical Pacific and Indian oceans by roughly $1^{\circ} \mathrm{C}$. In contrast, the tropical Pacific Ocean cooled by $2{ }^{\circ} \mathrm{C}$ more than the tropical Atlantic and Indian oceans in the Cpl-LGM simulation. Although SSTs in the east equatorial Pacific have been reported as $1.5-3.0^{\circ} \mathrm{C}$ cooler than the PI (Dubois et al., 2014; Kucera et al., 2005), the simulated cooling over much of the tropical Pacific appears excessive compared to previous simulations (Braconnot et al., 2007).

\subsubsection{Sea ice extent}

The Cpl-PI sea ice extent is consistent with estimates made using satellite measurements during the 1979-1987 period (Gloersen et al., 1993; Table 2). These measurements represent the first global estimates of sea ice coverage, and al- 

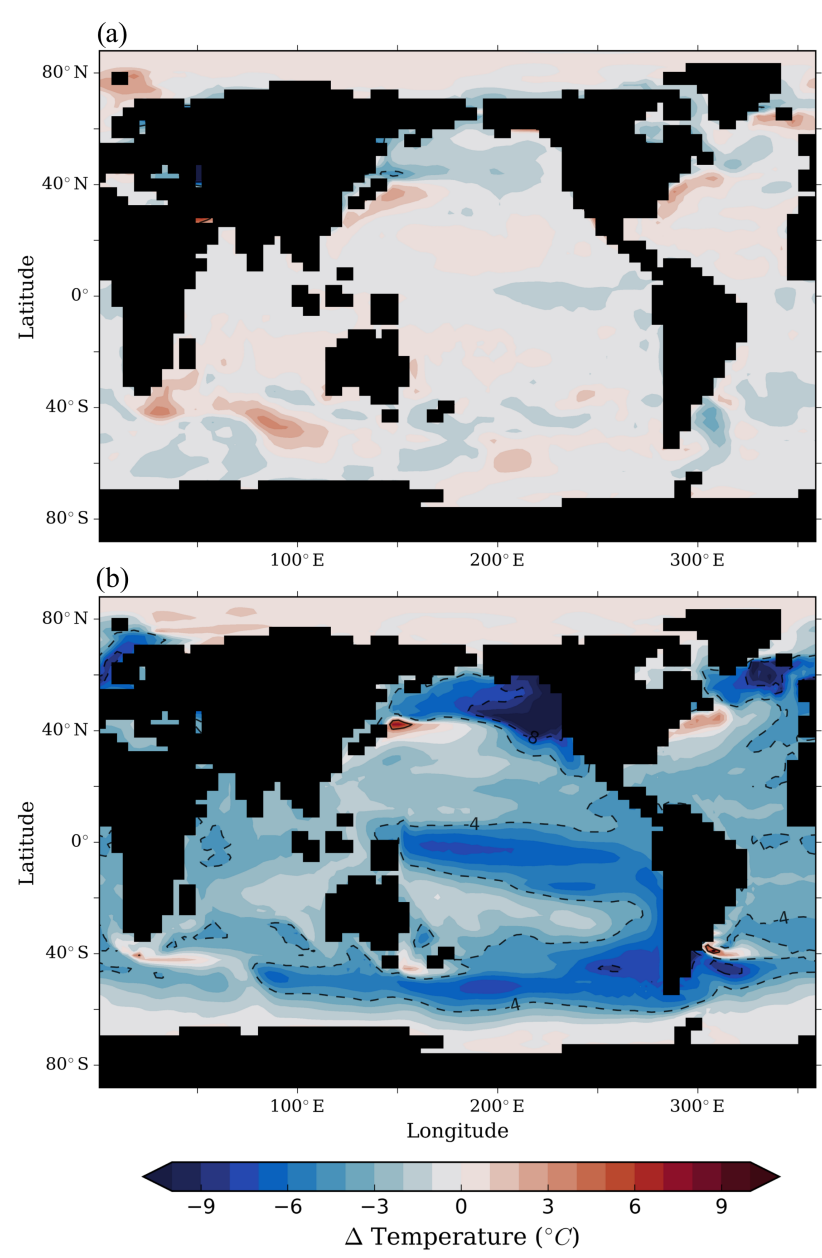

Figure 1. Annual sea surface temperature (SST) difference between (a) the coupled PI experiment, Cpl-PI and the observations from Levitus (2001) and (b) the difference between the coupled LGM and PI experiments (Cpl-LGM-Cpl-PI). Solid contour lines denote positive changes in SST by 4 and $8^{\circ} \mathrm{C}$, while negative changes in SST are denoted by dashed lines at 4 and $8^{\circ} \mathrm{C}$.

though there is evidence that sea ice has declined by $20 \%$ since the 1950s (Curran et al., 2003), the strong agreement between the Cpl-PI sea ice fields and the observations of Gloersen et al. (1993) provide a benchmark for assessing LGM sea ice changes.

Associated with cooler SSTs, sea ice coverage (fractional sea ice area $\geq 15 \%$ ) was greatly expanded in the Cpl-LGM for both hemispheres relative to the Cpl-PI (Fig. 2, Table 2). In the Southern Hemisphere, total sea ice coverage increased by $\sim 120$ and $\sim 225 \%$ at its seasonal maximum and minimum, respectively, relative to the Cpl-PI. In the Northern Hemisphere, total sea ice coverage increased by $\sim 145 \%$ and $\sim 105 \%$ at its seasonal maximum and minimum, respectively, relative to the Cpl-PI. These increases correspond to equatorward expansions of the sea ice field of between 5- $10^{\circ}$ around the Southern Ocean and in excess of $15^{\circ}$ in both the North Atlantic and Pacific oceans.

The simulated expansion of sea ice around much of the Southern Ocean agrees well with proxy reconstructions. Maximum sea ice extent reached as far north as $47^{\circ} \mathrm{S}$ in both the Atlantic and Indian sectors (Gersonde et al., 2005) and as far north as $55^{\circ} \mathrm{S}$ in the Pacific sector of the Southern Ocean (Benz et al., 2016; Gersonde et al., 2005; Fig. 2). The magnitude of growth in the Atlantic and Indian sectors has been tested and largely supported by subsequent studies (Collins et al., 2012; Xiao et al., 2016) and is consistent with our CplLGM sea ice field. In the Pacific sector, however, the simulated maximum sea ice edge extends well equatorward of the $55^{\circ} \mathrm{S}$ boundary that has been defined by Benz et al. (2016) (Fig. 2). By comparing the coverage of sea ice in the Southern Hemisphere of the Cpl-LGM $\left(\sim 46 \times 10^{6} \mathrm{~km}^{2}\right)$ with that estimated by Gersonde et al. $(2005)\left(\sim 39 \times 10^{6} \mathrm{~km}^{2}\right)$, we can attribute the simulated excess of sea ice in the glacial Southern Ocean to a possible overestimate in the Pacific sector.

The Cpl-LGM sea ice was broadly consistent with reconstructions in the North Atlantic, with the exception that too much ice covered the Nordic Seas. The central and eastern parts of the subpolar North Atlantic, including the Nordic Seas, are thought to have been at least seasonally ice-free (Pflaumann et al., 2003; De Vernal et al., 2005). The CplLGM sea ice field showed strong, year-round cover in these regions. However, better model-proxy agreement was produced in other parts of the North Atlantic. Perennial sea ice cover was present in the Greenland Sea and Fram Strait during the LGM (Müller et al., 2009; Telesiński et al., 2014). There is also evidence that winter sea ice reached south of Iceland to fill much of the Labrador Sea (Pflaumann et al., 2003) and extended along the eastern Canadian margin (De Vernal et al., 2005). These features were produced in the CplLGM simulation.

In the North Pacific, the Cpl-LGM sea ice field expanded across a large area. Proxy reconstructions indicate the presence of strong cover in the Okhotsk Sea (Sakamoto et al., 2005; Nürnberg and Tiedemann, 2004), the Japan Sea (Ikehara, 2003) and the western Bering Sea (Riethdorf et al., 2013) during the LGM, with seasonally ice-free conditions in the central west (Jaccard et al., 2005). Thus, like the North Atlantic, sea ice presence was likely more extensive in the western margins of the North Pacific, and this pattern is replicated by other climate models (Fig. 2). In the Cpl-LGM simulation, more intense sea ice cover developed in the west, but year-round cover also developed over the central North Pacific and contrasts directly with the findings of Jaccard et al. (2005), who argued for ice-free conditions during the summer. Thus, our simulated sea ice extent in the North Pacific may be an exaggeration. 

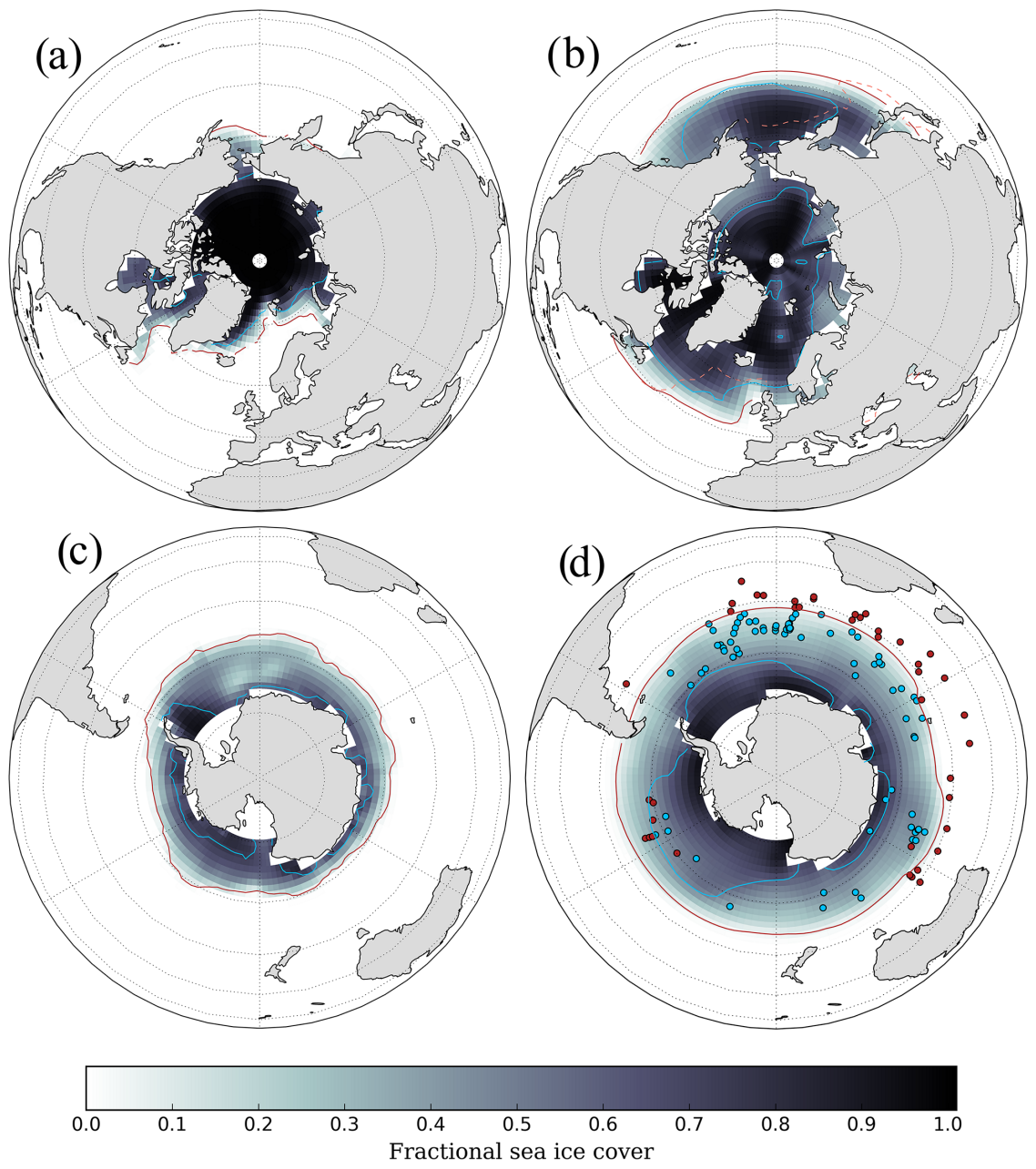

Figure 2. Annual average sea ice cover for (a) the Cpl-PI Northern Hemisphere, (b) the Cpl-LGM Northern Hemisphere, (c) the Cpl-PI Southern Hemisphere and (d) the Cpl-LGM Southern Hemisphere. The red and blue contour lines in each projection represent the maximum and minimum seasonal sea ice extents (where sea ice concentration equals $15 \%$ as per Gersonde et al., 2005). In (b), the dashed orange contour line represents the maximum seasonal sea ice extent produced by the Institut Pierre Simon Laplace (IPSL) climate system model, which took part in the PMIP3 LGM experiment, and is broadly consistent with the results of other PMIP3 models. In (d), the coloured markers represent locations were winter sea ice was deemed to have been present (blue) and absent (red) at the LGM according to Gersonde et al. (2005).

\subsubsection{Meridional overturning circulation}

The changes observed in the surface ocean within the CplLGM climate were accompanied by changes in the global meridional overturning circulation (Fig. 3; Table 2). The rate of Antarctic Bottom Water (AABW) formation in the Southern Ocean doubled between the Cpl-PI and Cpl-LGM experiments, increasing from 10.3 to $20.2 \mathrm{~Sv}$. An increase in surface density of $0.9 \mathrm{~kg} \mathrm{~m}^{-3}$ between 60 to $40^{\circ} \mathrm{S}$ drove this intensification and also strengthened transport by the Antarctic Circumpolar Current (ACC) from 140 to $309 \mathrm{~Sv}$. Meanwhile, the Atlantic Meridional Overturning Circulation (AMOC) weakened from 15.6 to $11.4 \mathrm{~Sv}$. The weakened glacial AMOC was also associated with a shoaling of its lower boundary from approximately 3000 to $1500 \mathrm{~m}$. As a result, much of the Atlantic Ocean below $1500 \mathrm{~m}$ was dominated by AABW as part of the lower overturning cell.

These changes in the lower and upper overturning cells were conducive to the development of a global overturning circulation dominated by a denser AABW and a shallower AMOC. These results are supported by numerous palaeonutrient tracers showing an increased presence of southern source waters within the deep North Atlantic Ocean during glacial periods (Curry and Oppo, 2005; Duplessy et al., 1988; Keigwin, 2004; Marchitto and Broecker, 2006; Oliver et al., 2010; Skinner et al., 2010). The prevailing interpretation of the palaeonutrient tracers is that the maximum depth of the AMOC was displaced above about $2000 \mathrm{~m}$ and that this shoaling facilitated the development of a saltier, more stratified glacial deep ocean (Adkins, 2013). Ferrari et al. (2014) 

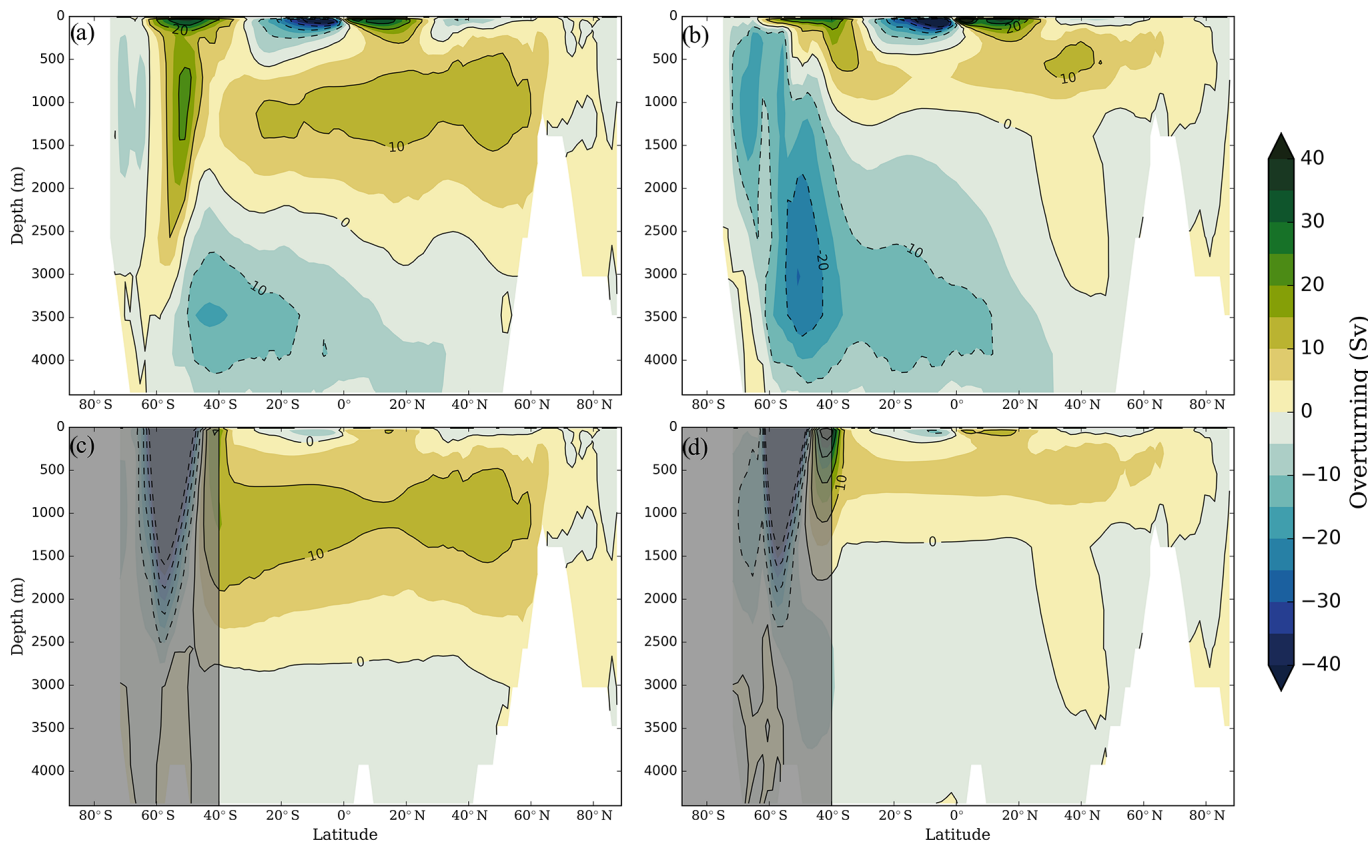

Figure 3. The upper panels depict the total meridional overturning stream function (Sv) for the global ocean in the (a) Cpl-PI and (b) CplLGM simulations. The bottom panels depict the total meridional overturning stream function (sv) for the Atlantic ocean in the (c) Cpl-PI and (d) Cpl-LGM simulations. Note that those latitudes corresponding to the Southern Ocean are obscured for (c, d) in the Atlantic Ocean, as these overturning velocities are invalid considering that waters can exit to the east and west and that the stream function does not account for these losses.

have linked these changed to the expansion of sea ice in the Southern Ocean, which caused a greater proportion of Circumpolar Deep Water to rise into a zone of negative buoyancy flux and thereby produce greater quantities of denser AABW.

However, contradictory changes in the glacial overturning circulation have been simulated in other climate system models. The rates of AABW formation tend to increase under LGM conditions (Otto-Bliesner et al., 2007), but responses of the AMOC among models are highly variable. In earlier experiments as part of the PMIP2 project, the AMOC response ranged between $40 \%$ above and below the PI rate of overturning (Weber et al., 2007). Our weakened ( 35\%) and shallower $(\sim 50 \%)$ glacial AMOC is therefore consistent with the lower bounds of these simulations, as are our rates of AABW formation (Table 2). More recent LGM simulations as part of the PMIP3 project, however, developed stronger and deeper glacial AMOCs (Muglia and Schmittner, 2015). Furthermore, a recent reconstruction of Southern Ocean circulation indicates that extreme intensifications of AABW formation and ACC transport at the LGM are unlikely (Lynch-Stieglitz et al., 2016). Consequently, these results challenge our simulated changes in meridional overturning, as well as the prevailing interpretation of palaeonutrient evidence.

Despite inconsistencies between climate model simulations, palaeonutrient reconstructions continue to support the existence of a shallower AMOC overlying southern source waters during glacial periods. Variations in the isotopic signature of Neodynium, for instance, indicate that AABW was more dominant in the deep ocean during the LGM and that its mixing with a glacial form of North Atlantic Deep Water (NADW) was more intense (Howe et al., 2016). These and other authors (Burckel et al., 2016) find further support for the presence of a shallower AMOC above $2500 \mathrm{~m}$. Moreover, simulated distributions of carbon isotopes across a range of idealised circulations have shown that a shallower AMOC is necessary to optimise model-proxy agreement at the LGM (Menviel et al., 2016). Importantly, our Cpl-LGM simulation developed an increased presence of AABW throughout the global deep ocean and the development of a shallower AMOC.

\subsection{LGM climate: biogeochemical fields}

The physical changes in the ocean between the Cpl-PI and the Cpl-LGM, as described above, caused significant changes in ocean biogeochemistry within the ocean-only simulations (Table 3). To assist in the discussion of the large-scale biogeochemical changes, we divide the upper and the deep ocean based on the $2000 \mathrm{~m}$ depth. This approach also allows for more clearly distinguishing between changes to the global overturning circulation, air-sea exchange and biological processes on the biogeochemical fields. 

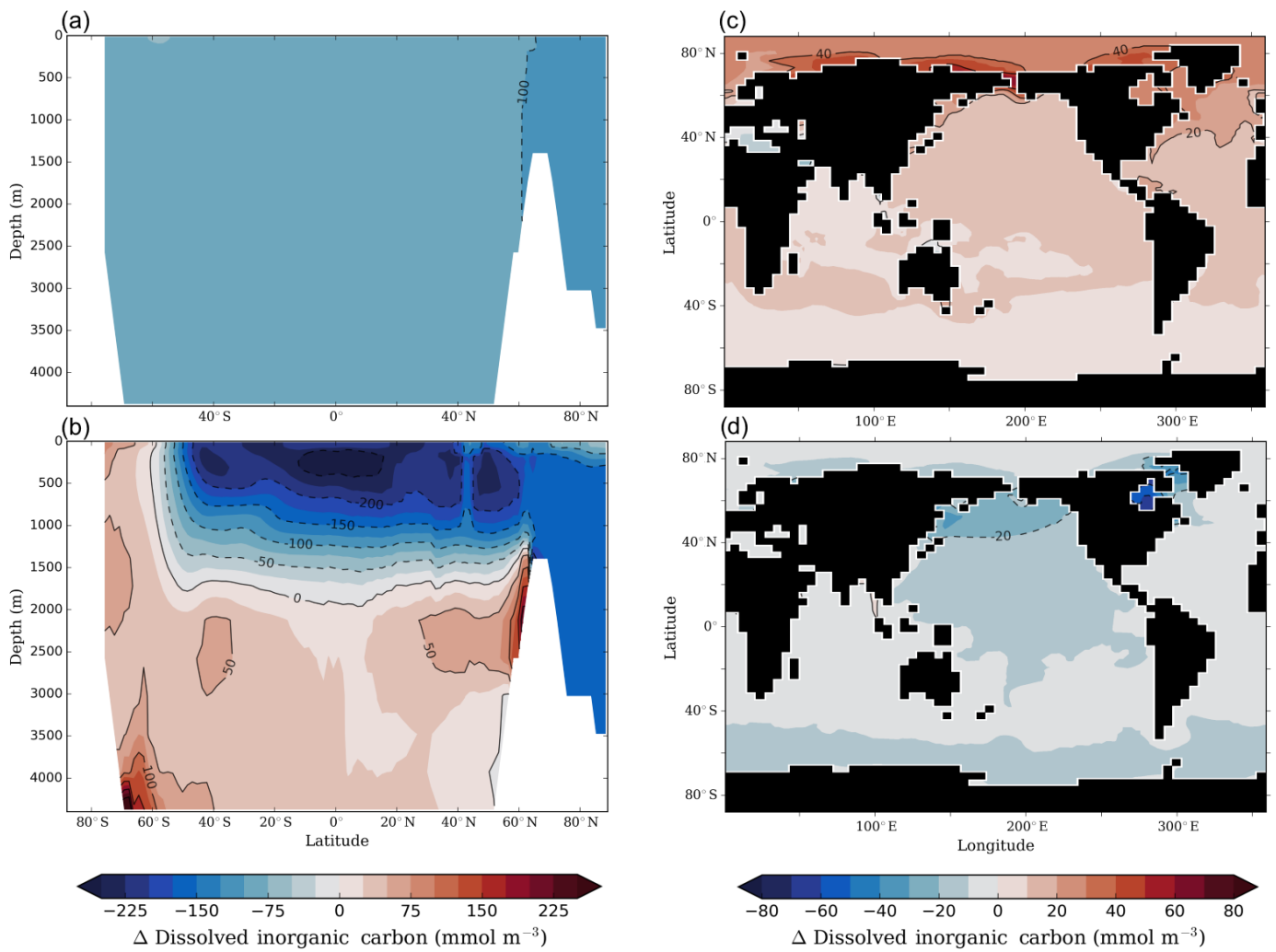

Figure 4. Changes in the concentration of dissolved inorganic carbon $\left(\mathrm{mmol} \mathrm{m}^{-3}\right)$ of the ocean due to physical differences between the pre-industrial (PI) and Last Glacial Maximum (LGM). Panels on the left represent the zonally averaged differences between experiments (a) $\mathrm{O}-\mathrm{PI} \mathrm{CO}_{2} \mathrm{LG}$ and (b) O-LGM with the O-PI experiment and therefore show total changes in carbon content due to all physical changes associated with the LGM climate. Panels on the right represent the depth-averaged differences between experiments (c) O-PI $\mathrm{L}_{\text {sol }}^{\mathrm{LGM}}$ and (d) $\mathrm{O}$ $\mathrm{PI}_{\text {ice }}^{\mathrm{LGM}}$ with the $\mathrm{O}-\mathrm{PI}_{\mathrm{CO}}^{\mathrm{LGM}}$ experiment and therefore represent the contribution of solubility and sea ice changes at the LGM to carbon storage in the ocean.

\subsubsection{Carbon}

For experiment O-LGM, the dissolved inorganic carbon (hereafter referred to as carbon) content of the ocean was $622 \mathrm{Pg} \mathrm{C}$ less than in the O-PI experiment (Fig. 4; Table 3). The net loss of carbon reflected the combined effect of physical changes to the ocean, which include an increase in solubility due to cooling, an expanded sea ice field, an altered overturning circulation and the tendency for outgassing caused by a lower $p \mathrm{CO}_{2}$. The physical changes were sufficient in combination to increase carbon in the deep ocean by $267 \mathrm{Pg} \mathrm{C}$. However, lowering the atmospheric $p \mathrm{CO}_{2}$ to $185 \mathrm{ppm}$ drove a large amount of carbon out of the ocean, causing a loss of $889 \mathrm{Pg} \mathrm{C}$ from waters in the upper $2000 \mathrm{~m}$. The combined effect of our simulated LGM physical state could therefore not overcome the equilibration with a lower atmospheric $p \mathrm{CO}_{2}$ concentration.

The increase in carbon content in the glacial deep ocean did suggest that despite the net loss caused by outgassing, the glacial ocean was indeed conducive to storing carbon. The loss of carbon from the ocean of experiment $\mathrm{O}-\mathrm{PI}_{\mathrm{CO}}^{\mathrm{LGM}}$ demonstrated this (Fig. 4; Table 3). The ocean carbon content of O-PI $\mathrm{CO}_{2} \mathrm{LGM}$ evolved to be $1290 \mathrm{Pg}$ less than in the OPI experiment, which placed the O-LGM carbon content as $668 \mathrm{Pg}$ greater than $\mathrm{O}-\mathrm{PI}_{\mathrm{CO}_{2}}^{\mathrm{LGM}}$. This confirmed that the glacial ocean had a greater ability to store carbon than the PI ocean.

To investigate this further, the individual contributions of glacial solubility, sea ice and circulation to carbon sequestration were determined by comparing the idealised experiments of O-PI $\mathrm{I}_{\text {ice }}^{\mathrm{LGM}}$ and $\mathrm{O}-\mathrm{PI}_{\text {sol }}^{\mathrm{LGM}}$ to O-PI $\mathrm{CO}_{2}^{\mathrm{LGM}}$. Under a PI circulation and a $p \mathrm{CO}_{2}$ of $185 \mathrm{ppm}$, solubility changes associated with the LGM increased the total carbon content of the ocean by $349 \mathrm{Pg} \mathrm{C}$. Meanwhile, sea ice expansion reduced carbon content by $160 \mathrm{Pg}$. The gains and losses of carbon in each experiment occurred in the high latitudes (Fig. 4). Carbon increased markedly in the Arctic and North Atlantic Ocean due to cooling, while decreases in export production caused by sea ice expansion reduced carbon content of the subarctic Pacific, Labrador Sea and across the Southern Ocean. Circulation changes associated with the glacial climate redistributed carbon from the upper to the deep ocean and were therefore responsible for the increase in deep-ocean 


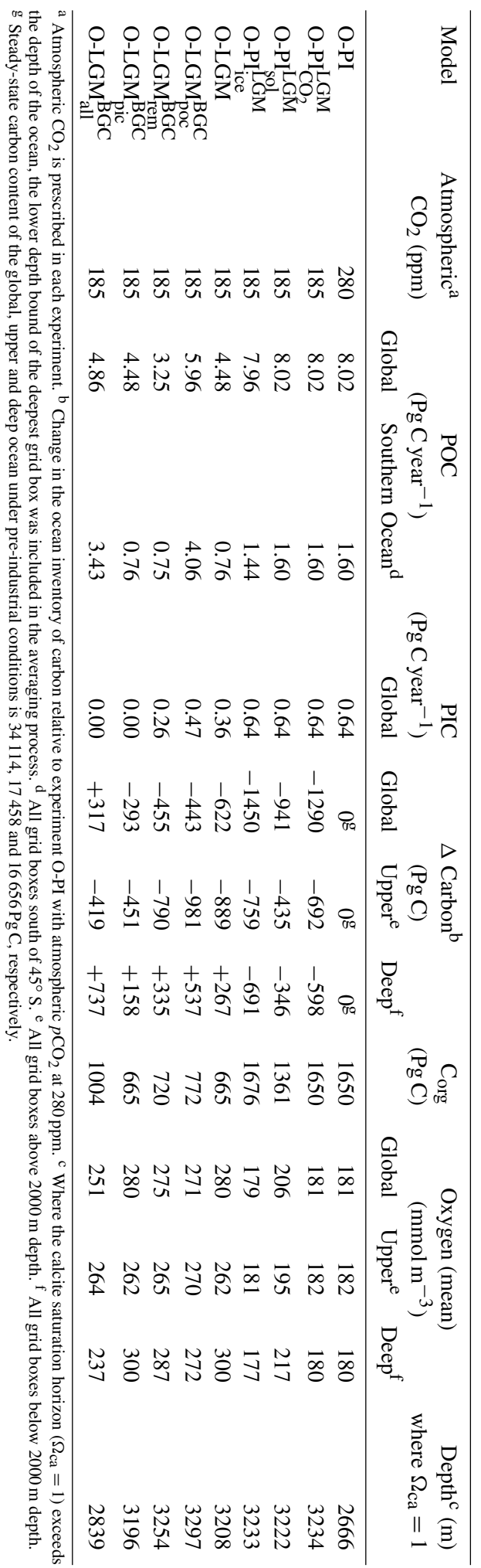

carbon in O-LGM. The isolated effect of the glacial circulation was the addition of $479 \mathrm{Pg} \mathrm{C}$, which was calculated by solving for the difference between the combined effect of solubility and sea ice $(189 \mathrm{PgC})$ and the gain between the $\mathrm{O}-\mathrm{LGM}$ and $\mathrm{O}-\mathrm{PI}_{\mathrm{CO}_{2}}^{\mathrm{LGM}}$ experiments (668 Pg C).

Therefore, we primarily implicate circulation and secondarily solubility changes as the physical drivers of oceanic carbon storage at the LGM, while presenting sea ice expansion as a mechanism for reducing ocean carbon storage. Regarding solubility, previous work has constrained the effect of glacial solubility on atmospheric carbon to approximately 15 ppm (Kohfeld and Ridgwell, 2009; Sigman and Boyle, 2000). By taking the $1290 \mathrm{Pg} \mathrm{C}$ difference between the O-PI and $\mathrm{O}-\mathrm{PI}_{\mathrm{CO}_{2}}^{\mathrm{LGM}}$ experiments and assuming an a priori addition of $520 \mathrm{PgC}$ in a glacial ocean (Ciais et al., 2011), we can attribute approximately $18 \mathrm{ppm}$ to our simulated solubility changes (Table 4). Our results are therefore roughly consistent with other estimates. The tendency for carbon to be released to the atmosphere would have been further reduced by storing more carbon in the deep ocean. We therefore note that circulation changes and cooling would have had a complementary effect on carbon sequestration and magnified their individual effects.

Regarding sea ice, a prevailing view is that sea ice expansion would enhance oceanic carbon storage by limiting airsea gas exchange (Stephens and Keeling, 2000). This theory largely focuses on the restriction of outgassing from carbonrich deep waters that upwell in the Southern Ocean. However, this neglects responses in the Northern Hemisphere and in the biological pump. In a seminal paper, Marinov et al. (2006) showed that export production and circulation in the Antarctic zone have a strong effect on atmospheric $\mathrm{CO}_{2}$. We found that light limitation of highly productive regions in both hemispheres caused by increased sea ice cover led to a global loss of $160 \mathrm{Pg} \mathrm{C}$, equivalent to $8 \mathrm{ppm} p \mathrm{CO}_{2}$. Similar responses have been simulated in other models that consider the impact of sea ice on biological production and do not consider temperature and salinity changes associated with sea ice growth (Kurahashi-Nakamura et al., 2007; Sun and Matsumoto, 2010).

Our results demonstrated that although the storage of carbon was enhanced in the glacial ocean $(668 \mathrm{PgC})$ due to physical changes, namely due to the overturning circulation, they could not overcome the loss of carbon (1290 Pg C) caused by equilibration with a lower atmospheric $p \mathrm{CO}_{2}$.

\subsubsection{Nutrients and export production}

Like carbon, phosphate $\left(\mathrm{PO}_{4}\right)$ concentrations in experiment O-LGM were redistributed from the upper to the deep ocean (Fig. 5). This change was driven by a strengthened $\mathrm{AABW}$ formation and is consistent with proxy reconstructions. Cadmium and $\delta^{13} \mathrm{C}$ measurements from the Atlantic Ocean show increased nutrient concentrations in the deep ocean but reduced levels above $2000 \mathrm{~m}$ at the LGM 
Table 4. A summary of the total changes in ocean carbon storage and their drivers between our simulated pre-industrial (PI) and Last Glacial Maximum (LGM) climates. We use the increase in carbon of our O-LGM $\mathrm{BGC}$ experiment of $317 \mathrm{Pg}$ C, which falls within the estimate range of ocean carbon storage at the LGM (Ciais et al., 2011), and our simulated loss of $1290 \mathrm{Pg}$ C from the PI ocean with an atmospheric $p \mathrm{CO}_{2}$ of $185 \mathrm{ppm}$ to determine the contribution of physical and biogeochemical drivers in ppm of $\mathrm{CO}_{2}$. For example, an addition of $1607 \mathrm{Pg} \mathrm{C}$ in excess of experiment $\mathrm{O}-\mathrm{PI}_{\mathrm{CO}_{2}}^{\mathrm{LGM}}(+317 \mathrm{Pg} \mathrm{C}$ in column 2$)$ would constitute a contribution of 95 ppm. BGC refers to biogeochemistry.

\begin{tabular}{lrr}
\hline Estimate & $\begin{array}{r}\Delta \text { Carbon } \\
(\mathrm{PgC})\end{array}$ & $\begin{array}{r}\text { Contribution } \\
\left(\mathrm{ppm} \mathrm{CO}_{2}\right)\end{array}$ \\
\hline Ciais et al. (2011) & $520 \pm 400^{\mathrm{a}}$ & +80 to 100 \\
LGM (all physical changes $)-$ modified $\mathrm{BGC}^{\mathrm{b}}\left(\mathrm{O}^{-} \mathrm{LGM}_{\mathrm{all}}^{\mathrm{BGC}}\right)$ & +317 & +95 \\
\hline PI - unmodified BGC $\left(p \mathrm{CO}_{2}=280 \mathrm{ppm}\right)$ & 0 & \\
PI - unmodified BGC $\left(p \mathrm{CO}_{2}=185 \mathrm{ppm}\right)$ & -1290 & 0 \\
\hline LGM (solubility) - unmodified BGC & -941 & +21 \\
LGM (sea ice) - unmodified BGC & -1450 & -9 \\
LGM (circulation) - unmodified BGC & -857 & +28 \\
LGM (all physical changes $)$ - unmodified BGC & -622 & +40 \\
LGM (biological pump) - modified BGC & -351 & +55 \\
\hline
\end{tabular}

${ }^{a}$ Estimate of increase in ocean carbon content during the LGM made by Ciais et al. (2011), whereby atmospheric carbon was reduced by $194 \pm 2 \mathrm{PgC}$ and terrestrial carbon was reduced by $330 \pm 400 \mathrm{PgC} .^{\mathrm{b}}$ Assumes all three biological modifications that were postulated (see Table 1, experiments $\mathrm{O}-\mathrm{LGM}_{\mathrm{poc}}^{\mathrm{BGC}}, \mathrm{O}-\mathrm{LGM}_{\mathrm{rem}}^{\mathrm{BGC}}$ and $\mathrm{O}-\mathrm{LGM}_{\mathrm{pic}}^{\mathrm{BGC}}$ ) occurred to provide an upper bound estimate of ocean carbon storage.

(Boyle, 1992; Gebbie, 2014; Marchitto and Broecker, 2006; Tagliabue et al., 2009).

A direct consequence of the redistribution of $\mathrm{PO}_{4}$ was the reduction in the production of particulate organic matter across many regions of the O-LGM ocean (Fig. 5). With the exception of the South Pacific and isolated areas in the subtropics, export production in the O-LGM experiment decreased relative to the O-PI experiment, so that global export production was $56 \%$ of O-PI. The global reduction was also illustrated by a decrease in regenerated carbon $\left(\mathrm{C}_{\text {org }}\right)$, which indicated that the biological carbon pump was weakened (Table 3). The reduction in export production and regenerated carbon for the O-LGM experiment is significant when compared with other studies that argue for a more efficient glacial biological pump than that of the Holocene (Galbraith and Jaccard, 2015; Schmittner and Somes, 2016). The weakened efficiency of our simulated biological pump can be attributed, in part, to a large decrease in export production from the subantarctic zone. This feature is in direct conflict with palaeoproductivity proxies in the Atlantic and Indian sectors of the subantarctic Ocean (Anderson et al., 2002, 2014; Chase et al., 2001; Jaccard et al., 2013; Nürnberg et al., 1997) and some parts of the Pacific sector (Bradtmiller et al., 2009; Lamy et al., 2014). Outside of the Southern Ocean, the reduction in export production in the O-LGM experiment is largely consistent with palaeoproductivity evidence (see Introduction).

\subsubsection{Carbonate chemistry}

The loss of phosphate from the upper ocean and its increase at depth was mirrored by changes in alkalinity and salinity, so that a more alkaline and saline signature of AABW, relative to NADW, dominated the deep ocean in experiment O-LGM. Alkalinity and salinity decreased by $66 \mathrm{mmol} \mathrm{Eq} \mathrm{m}^{-3}$ and $0.37 \mathrm{PSU}$ in the surface ocean and increased by $147 \mathrm{mmol} \mathrm{Eq} \mathrm{m}^{-3}$ and $2.71 \mathrm{PSU}$ in the deep ocean (Fig. 6).

Because the majority of LGM-PI change in salinity occurred in the deep ocean, the changes in carbonate chemistry across the surface ocean were small. Little change between experiments O-PI and O-LGM was found in the aragonite saturation state $\left(\Omega_{\mathrm{ar}}\right)$, which is a unitless index indicating under- and super-saturation at values below and above 1 (Fig. 7). Surface $\Omega_{\text {ar }}$ between $40^{\circ} \mathrm{S}$ and $40^{\circ} \mathrm{N}$ in O-LGM $\left(\Omega_{\mathrm{ar}}=3.8\right)$ was slightly lower than that of O-PI $\left(\Omega_{\mathrm{ar}}=4.0\right)$ but increased in the high-latitude oceans. Consequently, the simulated $\Omega_{\mathrm{ar}}=3.25$ isoline, the value at present used to define the location of viable coral reef conditions (HoeghGuldberg et al., 2007), was nearly unchanged between the O-LGM and O-PI experiments. Recent sonar and coring in the southern portion of the Great Barrier Reef (Abbey et al., 2011; Yokoyama et al., 2011) have detected the presence of drowned coral reefs that existed at the LGM as far south as reefs present today. Such observations are consistent with our O-LGM experiment and indicates that the extent of viable coral reefs was unlikely to have been significantly different at the LGM relative to today.

However, the magnitude of increase in alkalinity in the glacial deep ocean, which was not accompanied by a stoichiometrically matched increase in carbon, caused unrealistic increases in the calcite saturation horizon $\left(\Omega_{\mathrm{ca}}=1\right)$. The average position of the calcite saturation horizon increased 

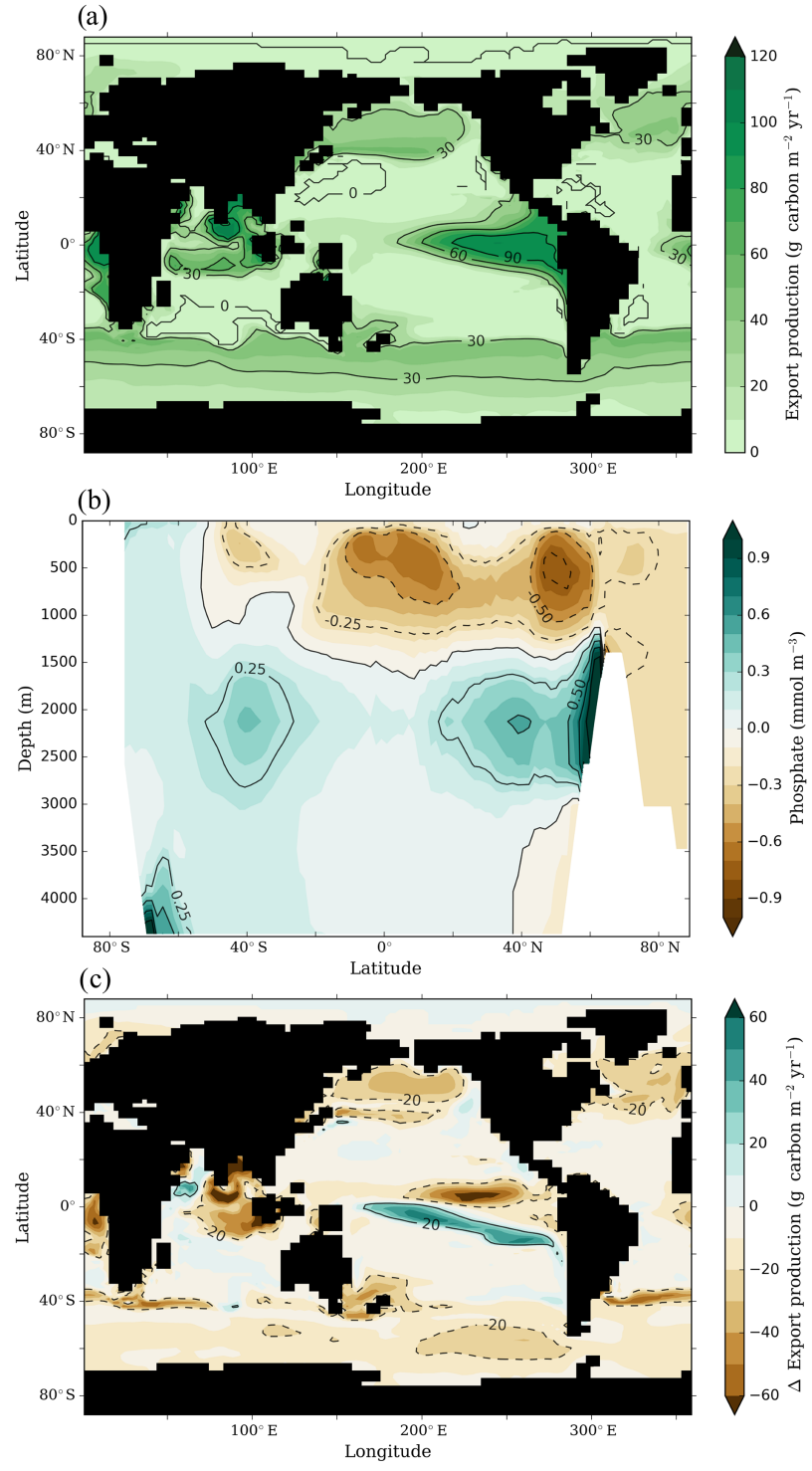

Figure 5. Changes in the export production of particulate organic matter (POC) and Phosphate concentrations between the O-LGM and O-PI experiments. (a) Annually averaged export of POC from the upper $50 \mathrm{~m}\left(\mathrm{~g} \mathrm{C} \mathrm{m}^{-2}\right.$ year $\left.^{-1}\right)$ for O-PI, (b) the O-LGM-O-PI difference in Phosphate concentrations $\left(\mathrm{mmol} \mathrm{m}^{-3}\right)$ and (c) the $\mathrm{O}$ LGM-O-PI difference in export production of POC from the upper $50 \mathrm{~m}\left(\mathrm{~g} \mathrm{C} \mathrm{m}^{-2}\right.$ year $\left.^{-1}\right)$.

from $2666 \mathrm{~m}$ in O-PI to $3208 \mathrm{~m}$ in O-LGM. While this increase may seem modest, the increase exceeded the ocean floor over the majority of the ocean, so that seawater was completely saturated for calcite outside of the eastern tropical Pacific (Fig. 8). There is strong evidence that the carbonate chemistry of the LGM ocean was not appreciably different to the late Holocene ( $\mathrm{Yu}$ et al., 2014), and this information places our simulated changes in deep-ocean $\Omega_{\mathrm{ca}}$ at the LGM as unrealistic.
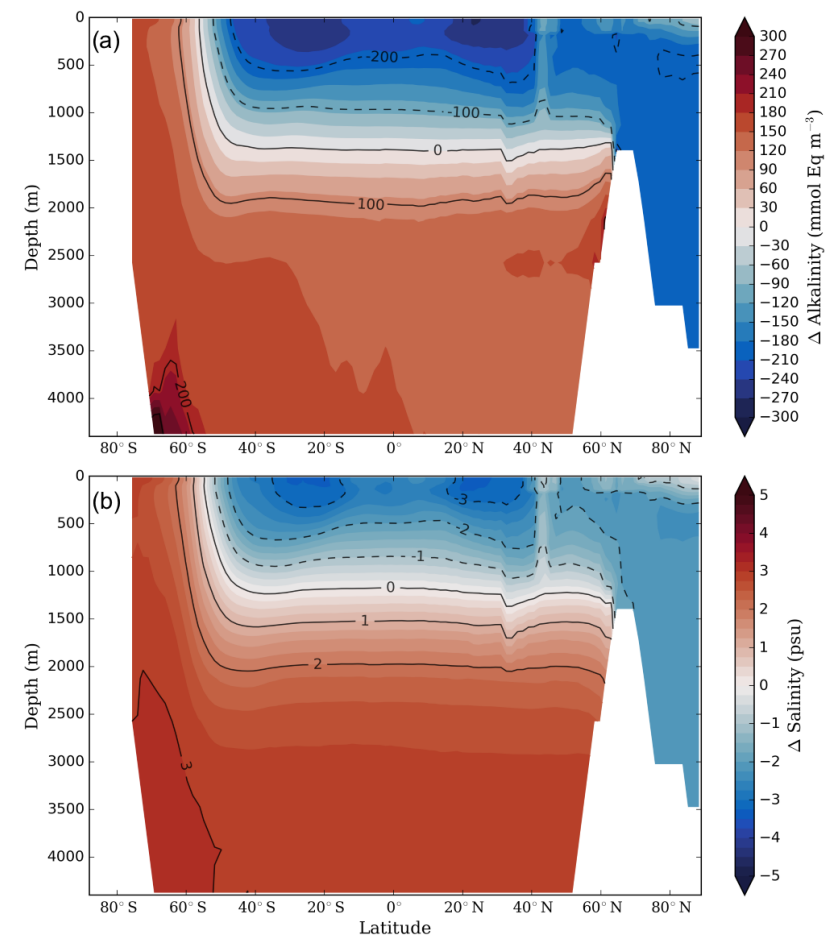

Figure 6. Change in the zonally averaged global distribution of (a) alkalinity $\left(\mathrm{mmol} \mathrm{Eq} \mathrm{m}^{-3}\right.$ ) and (b) salinity (PSU) between the OLGM and O-PI experiments (O-LGM-O-PI). Despite the strong reduction in salinity in the upper ocean of the O-LGM experiment relative to O-PI, the whole-ocean salt content was greater by 1.0 PSU.

\subsubsection{Dissolved oxygen}

Experiment O-PI produced a global average oxygen concentration of $\sim 181 \mathrm{mmol} \mathrm{O}_{2} \mathrm{~m}^{-3}$, similar to the PI global average of about $178 \mathrm{mmol} \mathrm{O}_{2} \mathrm{~m}^{-3}$ (Garcia, 2005). The combination of cooler SSTs, an enhanced subduction of AABW and the reduction in export production in experiment O-LGM dramatically increased the oxygen content in both the upper and deep ocean by $\sim 80$ and $\sim 120 \mathrm{mmol} \mathrm{m}^{-3}$, respectively, which constituted a global increase of $55 \%$ (Fig. 9; Table 3).

The increase in dissolved oxygen in O-LGM was considerable but agreed well with proxy reconstructions for the upper ocean. The oxygen-poor intermediate waters of the western North Pacific (Ishizaki et al., 2009; Shibahara et al., 2007), eastern North Pacific (Cannariato and Kennett, 1999; Cartapanis et al., 2011; Chang et al., 2014; Dean, 2007; Nameroff et al., 2004; Pride et al., 1999; Ohkushi et al., 2013; van Geen et al., 2003), eastern South Pacific (Martinez et al., 2006; Muratli et al., 2010; Salvatteci et al., 2016), equatorial Pacific (Leduc et al., 2010) and Indian Ocean (Reichart et al., 1998; Suthhof et al., 2001; van der Weijden et al., 2006) were better oxygenated at the LGM relative to the PI climate. An important consequence of oxygenating the upper ocean is a reduction in the strength of denitrification in these regions. Sedimentary $\delta^{15} \mathrm{~N}$ records suggest that global aggregate rates of 

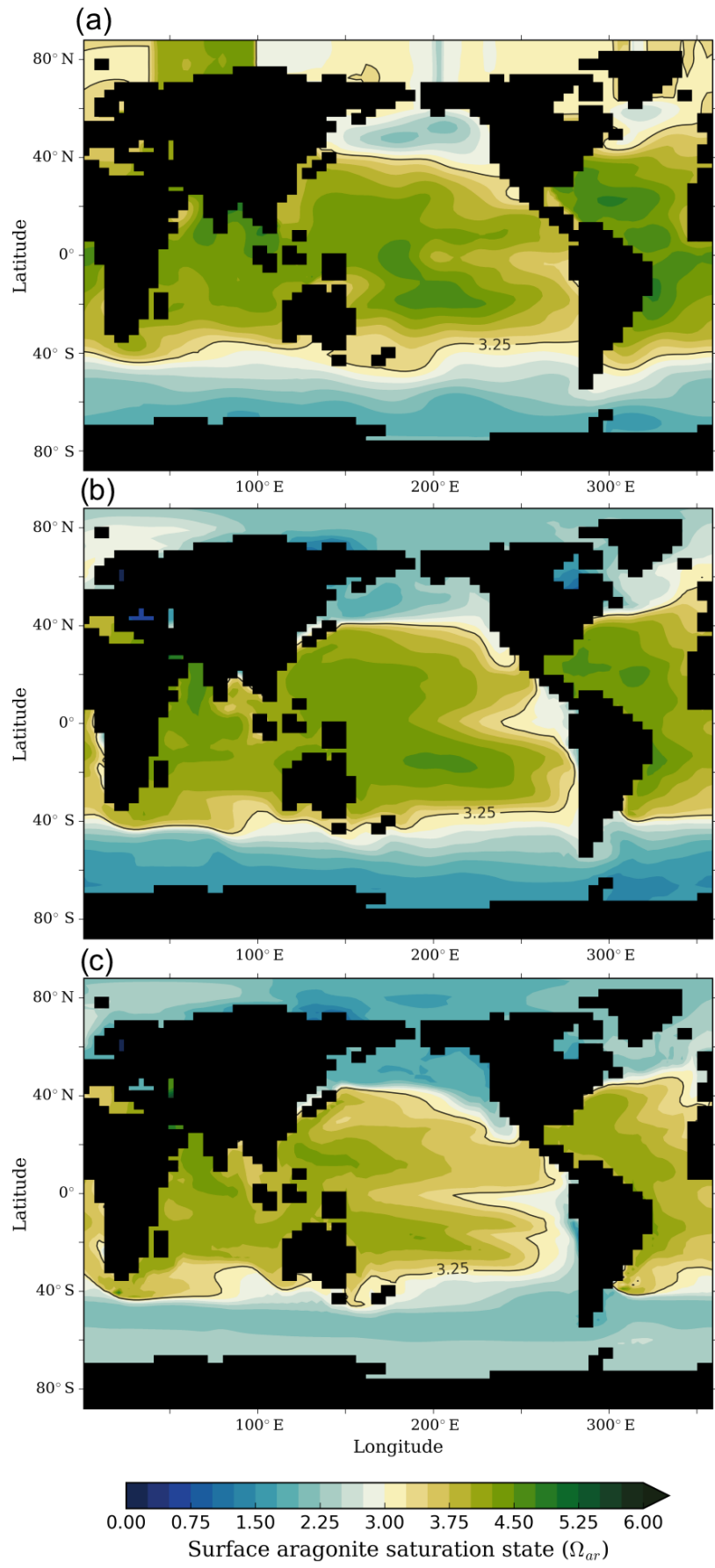

Figure 7. The annual average surface aragonite saturation state $\left(\Omega_{\mathrm{ar}}\right)$ calculated from (a) the observations of Key et al. (2004), (b) the O-PI experiment and (c) the O-LGM experiment. (a)
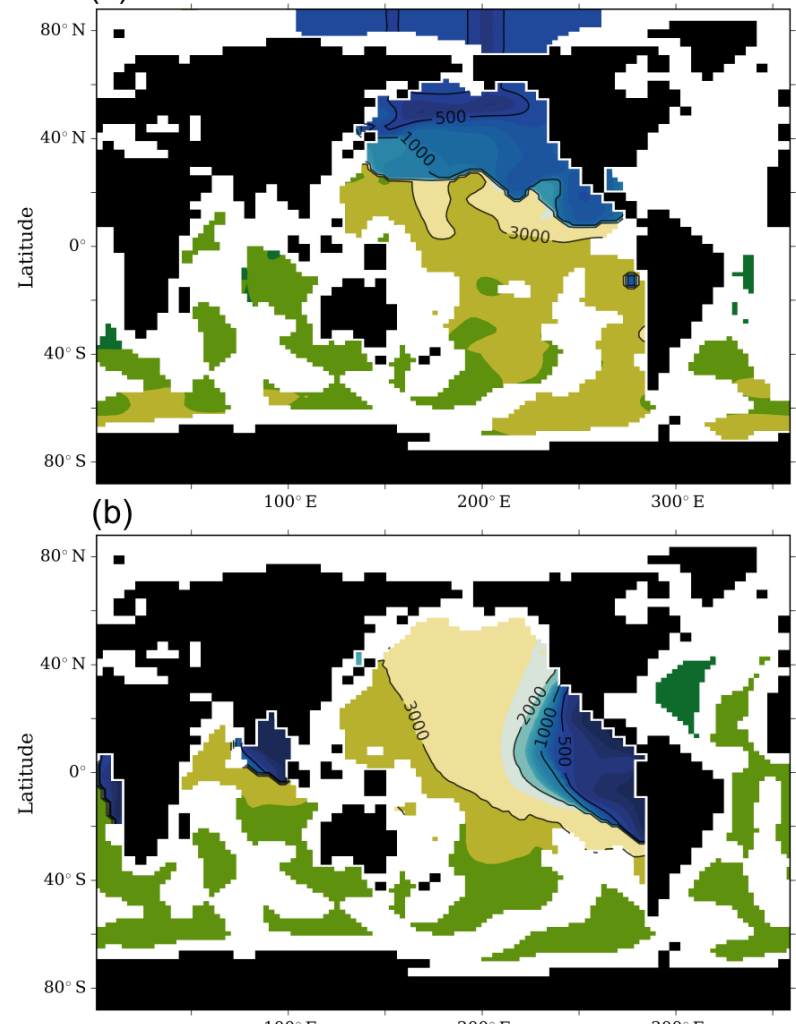

(c)

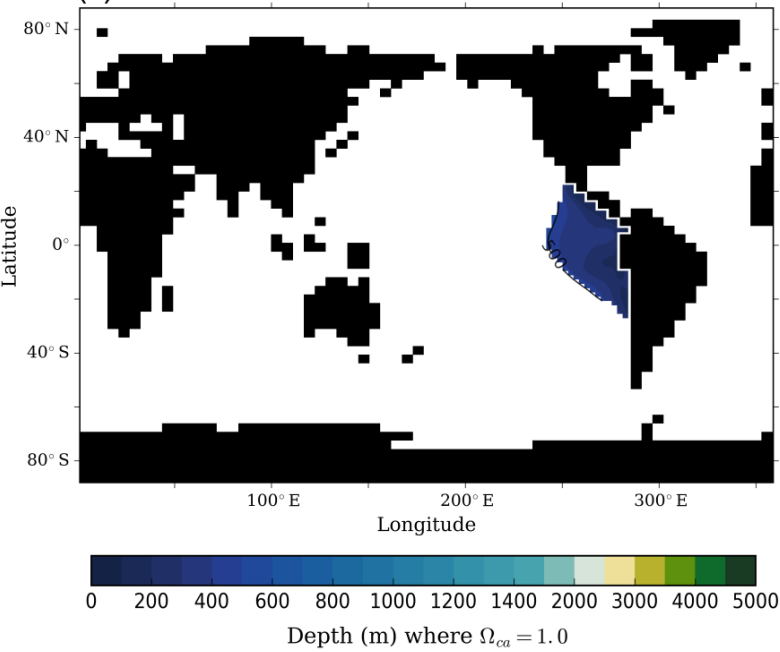

Figure 8. The depth at which calcite becomes undersaturated in the water column (where $\Omega_{\mathrm{ca}}=1$ ) calculated from (a) the observations of Key et al. (2004) (global mean calcite saturation horizon: $2610 \mathrm{~m}$ ), (b) the O-PI experiment (global mean calcite saturation horizon: $2666 \mathrm{~m}$ ) and (c) the O-LGM experiment (global mean calcite saturation horizon: $3208 \mathrm{~m}$ ). The contour lines represent 500, 1000, 2000 and $3000 \mathrm{~m}$ depth. Note that the O-LGM experiment, which is unmodified in its biogeochemistry relative to the O-PI experiment, is completely saturated for calcite across the majority of the ocean (white space). 

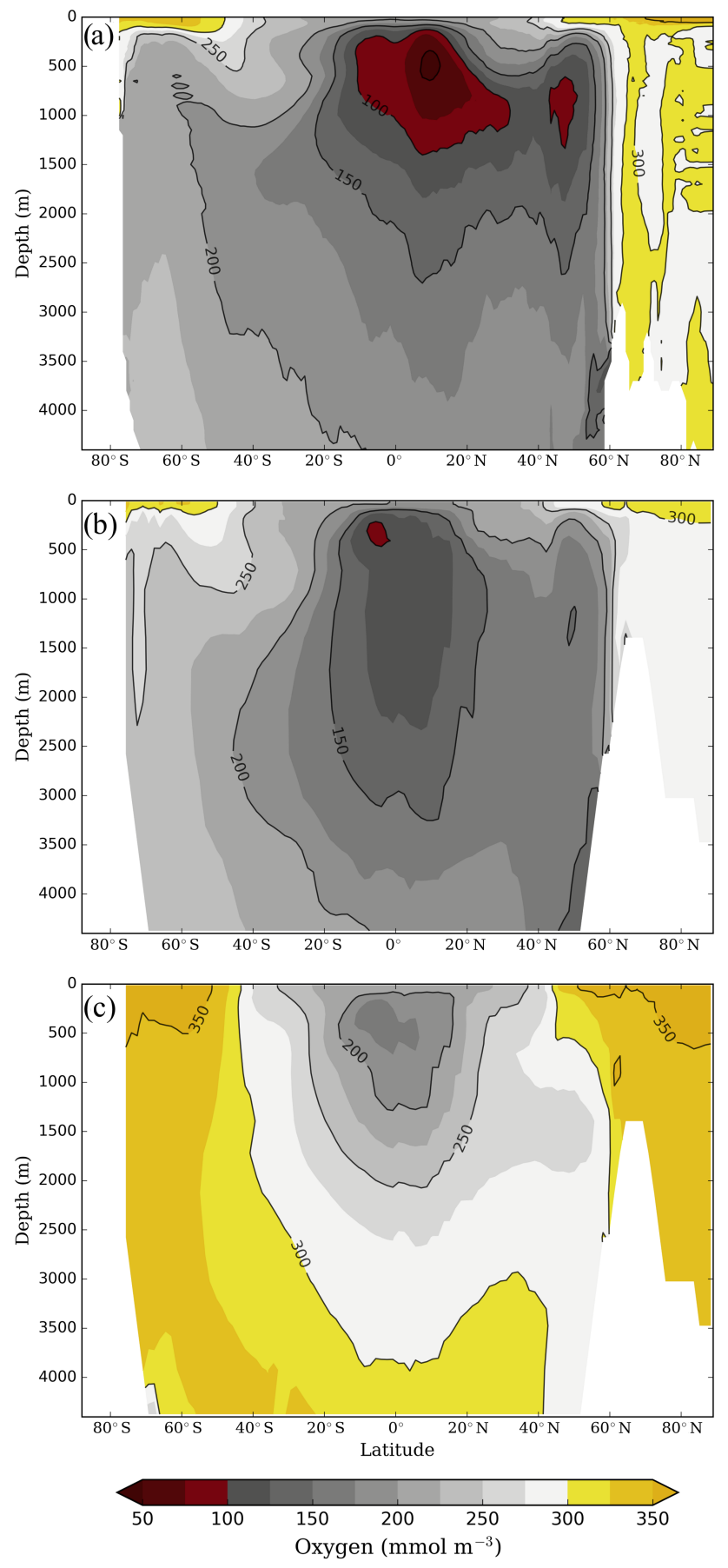

Figure 9. Zonally averaged dissolved oxygen concentrations $\left(\mathrm{mmol} \mathrm{m}{ }^{-3}\right)$ in (a) the modern ocean according to the World Ocean Atlas (Garcia et al., 2013), (b) the O-PI experiment and (c) the OLGM experiment.

water column denitrification rates over the past 200000 years were lower during glacial periods and higher during interglacial periods (Galbraith et al., 2004), and this is consistent with the simulated oxygenation of the upper ocean.
However, dissolved oxygen concentrations in the deep ocean increased to an average of $300 \mathrm{mmol} \mathrm{O}_{2} \mathrm{~m}^{-3}$ in $\mathrm{O}-$ LGM, and this contrasts starkly with existing palaeoclimate reconstructions. Deep waters of the Indian Ocean (Murgese et al., 2008; Sarkar et al., 1993; Schmiedl and Mackensen, 2006), North Atlantic (Hoogakker et al., 2014), Southern Ocean (Chase et al., 2001; Jaccard et al., 2016) and equatorial Pacific (de la Fuente et al., 2015) were poorly ventilated at the LGM relative to the Holocene. Drawing on a global compilation of similar studies, Jaccard and Galbraith (2012) and Jaccard et al. (2014) demonstrated that the deep ocean was largely deoxygenated relative to the Holocene on a global scale. While the increase in oxygen concentrations in the upper ocean aligned with the direction of change inferred from proxies, the response in the deep ocean can be considered unrealistic.

\subsection{Importance of ocean biogeochemistry for climate}

The carbon content, export production field, carbonate chemistry and deep-ocean oxygen content of experiment O-LGM are outstanding in their disagreement with proxy evidence. Notably, $622 \mathrm{Pg} \mathrm{C}$ was lost from experiment O-LGM relative to O-PI. The standard LGM simulation was therefore unable to explain the glacial-interglacial drawdown of atmospheric $\mathrm{CO}_{2}$, despite the existence of a physical ocean state within realistic bounds. If we are to reconcile the biogeochemistry of the glacial ocean with that inferred from proxy evidence, we must therefore consider altering ocean biogeochemistry.

\subsubsection{Reconciling the carbon budget}

Three plausible modifications to ocean biogeochemistry (see methods) were considered: (1) increased POC export production, (2) increased depth of POC remineralisation and (3) reduced PIC export. In the following we step through the changes to carbon content caused by each modification, and the reader is directed to Table 3 for reference.

1. Experiment O-LGM $\mathrm{Lac}_{\text {poc }}^{\mathrm{BGC}}$. Although the scaling factor controlling the export production of organic matter was increased 10-fold, the actual increase in POC export production averaged over the global ocean was more modest at roughly $30 \%$. Because most of the ocean became phosphate limited as greater quantities of nutrients were redistributed into the deep ocean, the increase in export production in experiment O-LGM poc was only felt in those regions where $\mathrm{PO}_{4}$ was not limiting. The subantarctic zone of the Southern Ocean experienced the greatest increase in export production $(\sim 250 \%)$, followed by a few small regions along the Chilean margin and in the northwest Pacific (Fig. 10). These regional responses caused the global net export production rate to increase from 4.48 to $5.96 \mathrm{Pg} \mathrm{C}_{\text {year }}{ }^{-1}$. Although this rate of POC export production was still 
lower than the O-PI experiment of $8.02 \mathrm{PgC} \mathrm{Cear}^{-1}$, this increased carbon content by $179 \mathrm{Pg} \mathrm{C}$.

2. Experiment O-LGM $\mathrm{rGC}$. The shift of organic matter to depth was associated with a global reduction in POC export production of $\sim 1.2 \mathrm{Pg} \mathrm{C}_{\text {year }}{ }^{-1}$ as remineralisation released $\mathrm{PO}_{4}$ and carbon further from the photic zone. Despite the reduction in the biological pump, the bulk transfer of POC to depth generated an increase in ocean carbon storage of $167 \mathrm{Pg} \mathrm{C}$.

3. Experiment O-LGM pic . The elimination of PIC in the simulated glacial ocean increased the solubility of $\mathrm{CO}_{2}$ in the surface ocean and enabled the ocean to store an additional $329 \mathrm{Pg} \mathrm{C}$.

Independently, none of the above modifications were able to increase ocean carbon content relative to the O-PI experiment (O-LGM $\mathrm{Loc}_{\text {poc }}^{\mathrm{BGC}}-443 \mathrm{Pg}$ C; O-LGM $\mathrm{LGm}_{\mathrm{rem}}^{\mathrm{BGC}}:-455 \mathrm{Pg} \mathrm{C}$; O$L_{\text {GMic }}^{\text {BGC }:-293 ~ P g ~ C) . ~ H o w e v e r, ~ b y ~ e m p l o y i n g ~ a l l ~ t h r e e ~ b i o-~}$ geochemical modifications in one experiment (experiment O-LGM ${ }_{\text {all }}^{\mathrm{BGC}}$ ), the glacial ocean was able to store an additional $939 \mathrm{Pg} \mathrm{C}$ more than experiment O-LGM and $317 \mathrm{Pg} \mathrm{C}$ more than O-PI.

This magnitude of increase places our glacial ocean state within the plausible bounds required to offset the loss of atmospheric and terrestrial carbon reported by Ciais et al. (2011) of $\sim 520 \pm 400 \mathrm{Pg} \mathrm{C}$ at the LGM (Table 4). By assuming a glacial-interglacial difference in atmospheric $\mathrm{CO}_{2}$ of $95 \mathrm{ppm}$ and applying this to our changes in carbon content, we attribute roughly $40 \mathrm{ppm}$ to changes in ocean physics and $55 \mathrm{ppm}$ to changes in the biological pump. Within the physical changes, $28 \mathrm{ppm}$ is attributed to the reorganisation of the global overturning circulation, while $12 \mathrm{ppm}$ can be attributed to changes in surface properties, including sea ice expansion, cooling and salinification.

\subsubsection{Reconciling export production}

Of the three biogeochemical modifications applied to the LGM ocean, only two had an effect on POC export, as the amount of PIC exported from the photic zone has no influence on the amount of POC export. Deepening the remineralisation of $\mathrm{POC}\left(\mathrm{O}-\mathrm{LGM}_{\mathrm{rem}}^{\mathrm{BGC}}\right)$ shifted a greater fraction of regenerated $\mathrm{PO}_{4}$ into the deep ocean, which resulted in a global reduction of export production. Increasing the scaling factor $\left(\mathrm{O}-\mathrm{LGM}_{\mathrm{poc}}^{\mathrm{BGC}}\right)$, however, caused an increase in global export production from 4.48 to $5.96 \mathrm{Pg} \mathrm{C}_{\text {year }}{ }^{-1}$. Most of this increase occurred in the Southern Ocean, particularly the subantarctic zone, and in a few isolated pockets in the northwest Pacific and North Atlantic where excess nutrients were available (Fig. 10).

The increase in the scaling factor dominated the change in export production produced when combining all three biogeochemical modifications (O- $\left.\mathrm{LGM}_{\mathrm{all}}^{\mathrm{BGC}}\right)$. The strong increase in export production observed in the subantarctic was (a)

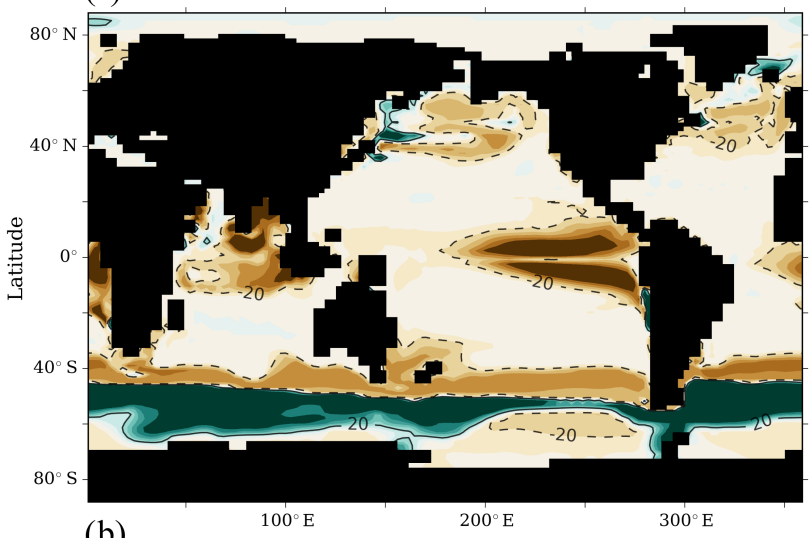

(b)

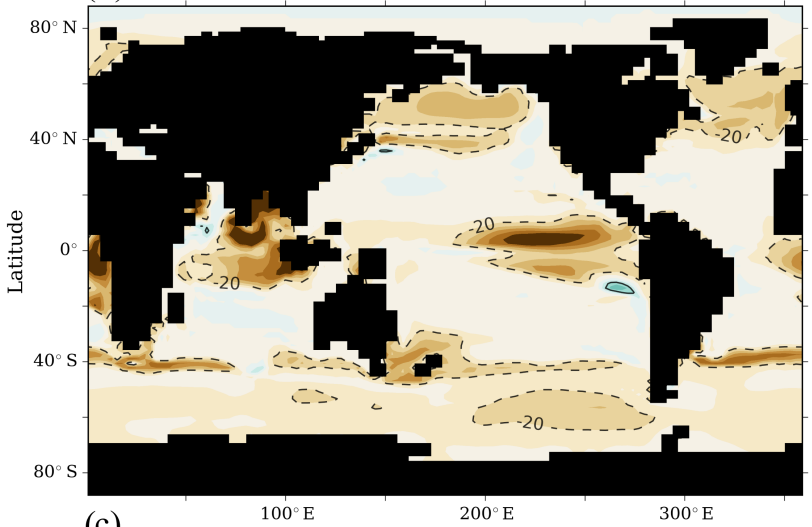

(c)

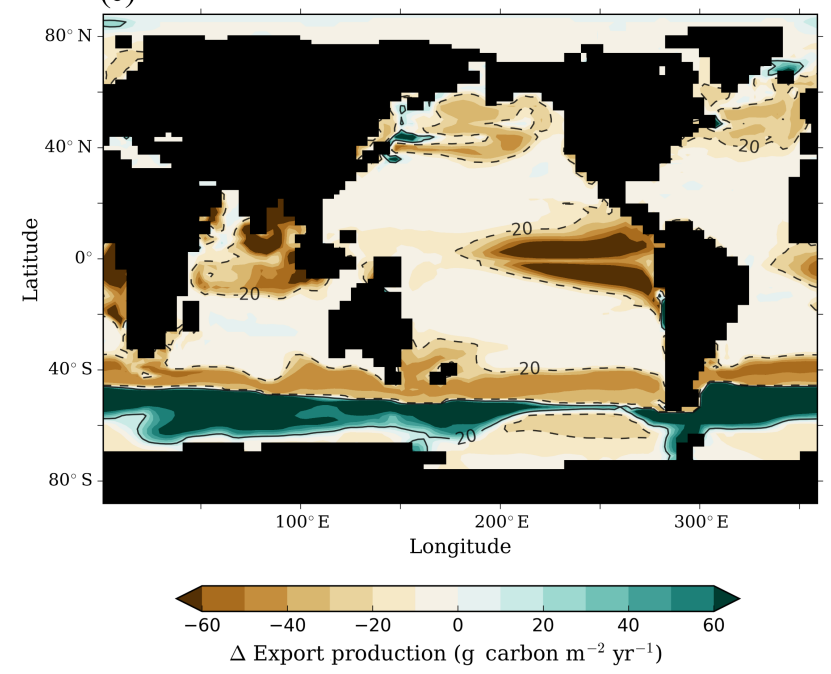

Figure 10. Change in annually averaged export of particulate or-

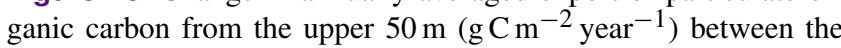
LGM and PI from the experiments with modified biogeochemical formulations for (a) O-LGM $\mathrm{Loc}_{\text {poc }}^{\mathrm{BGC}}$ O-PI, (b) O-LGM rem $-\mathrm{O}$ PI and (c) O-LGM $\mathrm{Ball}$ - O-PI. It should be noted that the export production field of particulate organic carbon for experiment $\mathrm{O}$ $\mathrm{LGM}_{\text {pic }}^{\mathrm{BGC}}$, whereby particulate inorganic carbon was set to zero, did not differ from unmodified experiment O-LGM and is therefore not shown. For this comparison, the reader is directed to Fig. 5. 

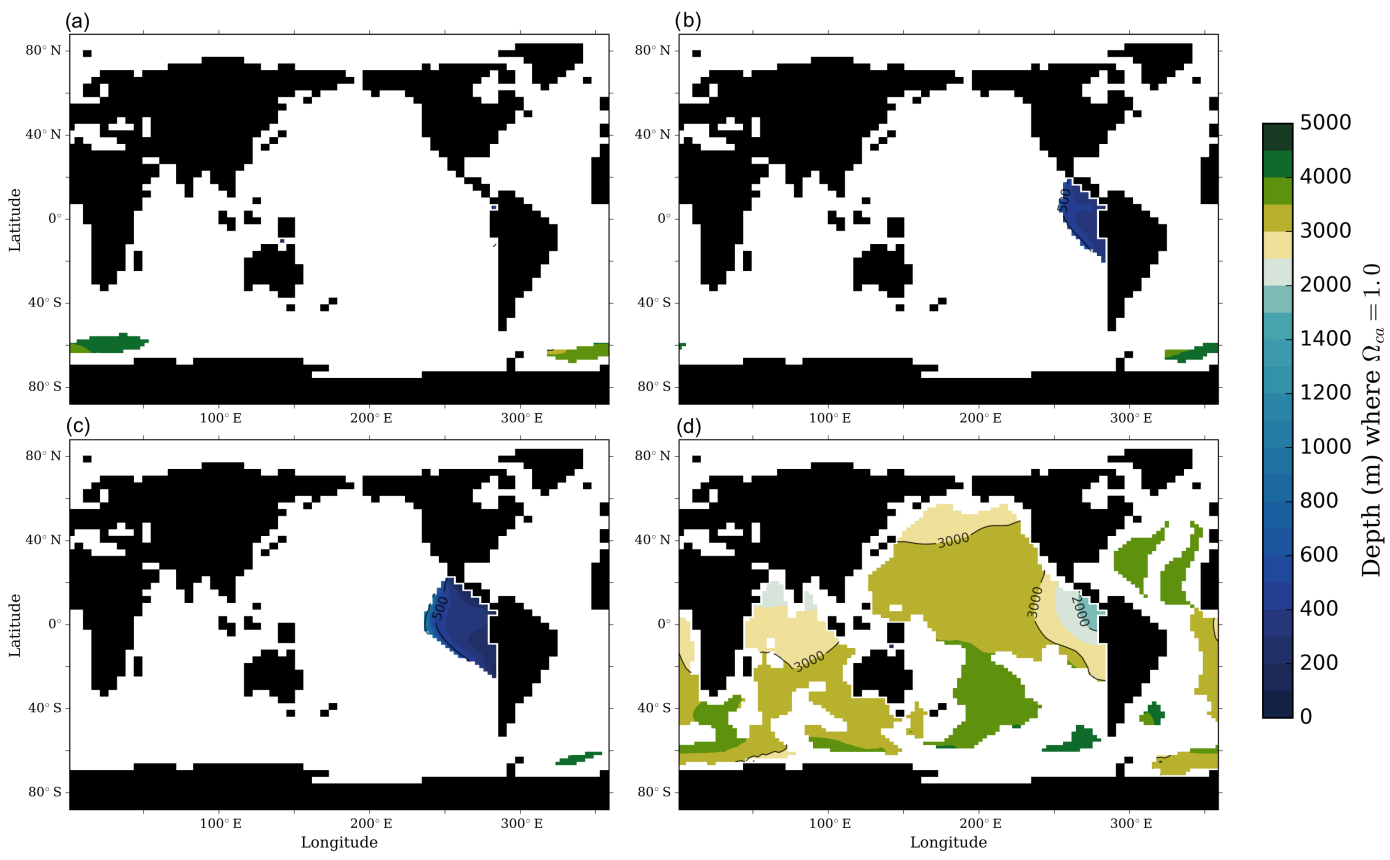

Figure 11. The depth at which calcite becomes undersaturated in the water column (where $\Omega_{\mathrm{ca}}=1$ ) for the experiments with modified biogeochemical formulations. (a) $\mathrm{O}-\mathrm{LGM}_{\text {poc }}^{\mathrm{BGC}}$, (b) $\mathrm{O}-\mathrm{LGM}_{\mathrm{rem}}^{\mathrm{BGC}}$, (c) $\mathrm{O}-\mathrm{LGM}_{\text {pic }}^{\mathrm{BGC}}$ and (d) O-LGM $\mathrm{BGC}$. The white areas in the ocean are regions where calcite is completely saturated throughout the water column.

clearly replicated within this experiment and reconciles our simulated export production field with current evidence of productivity at the LGM. In the Southern Ocean, the Atlantic and Indian sectors of the subantarctic zone experienced a greater flux of organics (Anderson et al., 2002, 2014; Chase et al., 2001; Jaccard et al., 2013; Nürnberg et al., 1997). Whether this was also the case for the Pacific sector remains under debate, with some evidence for increase (Bradtmiller et al., 2009; Lamy et al., 2014) and some for no change (Bostock et al., 2013; Chase et al., 2003). Meanwhile, it is widely accepted that waters south of the Antarctic Polar Front were reduced in their productivity (Bostock et al., 2013; Chase et al., 2003; Elderfield and Rickaby, 2000; Francois et al., 1997; Frank et al., 2000; Kohfeld et al., 2005; Kumar et al., 1995; Mortlock et al., 1991; Ninnemann and Charles, 1997; Shemesh et al., 1993), likely due to increased sea ice extent (Benz et al., 2016; Gersonde et al., 2005; Jaccard et al., 2013) and stratification (Anderson et al., 2014; Jaccard et al., 2005).

In experiment $\mathrm{O}-\mathrm{LGM}_{\mathrm{all}}^{\mathrm{BGC}}$, net export production remained less than the in O-PI experiment by $3.16 \mathrm{Pg} \mathrm{C}_{\text {year }}{ }^{-1}$ despite the application of biogeochemical modifications. The weakened carbon transfer to the interior ocean was also observed in the regenerated carbon content of the ocean $\left(\mathrm{C}_{\mathrm{org}}\right)$, which was $646 \mathrm{Pg}$ less than in the O-PI experiment (Table 3). The net decline in export production observed in this study was dominated by the decline in tropical and subtropical waters. Many palaeoproductivity studies located outside of the subantarctic zone have found weakened produc- tivity at the LGM (Chang et al., 2014, 2015; Costa et al., 2016; Crusius et al., 2004; Kohfeld et al., 2005; Kohfeld and Chase, 2011; Jaccard et al., 2005; McKay et al., 2015; Ortiz et al., 2004; Riethdorf et al., 2013; Salvatteci et al., 2016; Singh et al., 2011; Thomas et al., 1995). Additionally, an enhanced utilisation of available nutrients in the subantarctic zone (Martinez-Garcia et al., 2014) would reduce the nutrient content of intermediate waters formed in the Southern Ocean and would thus reduce the delivery of nutrients to lower latitudes (Sarmiento et al., 2004). This mechanism coupled with cooler temperatures caused reductions in export production across much of the mid- and lower-latitude oceans in experiment $\mathrm{O}-\mathrm{LGM}_{\mathrm{all}}^{\mathrm{BGC}}$, which maintains the qualitative agreement between the simulated export production field and proxy observations. However, the global weakening of the biological pump in our simulations is contrary to proxy and model-based evidence for a strengthened biological pump ( $>\mathrm{C}_{\text {org }}$ ) at the LGM (Galbraith and Jaccard, 2015; Schmittner and Somes, 2016). Hence, while we present improved spatial agreement between O-LGMall $\mathrm{BGC}$ and palaeoproductivity proxies at the LGM, which was essential to increasing the carbon content of the ocean, we note that additional increases in the export production field may be valid.

\subsubsection{Reconciling carbonate chemistry}

There is strong evidence that the carbonate chemistry of the glacial deep ocean was not appreciably different to the late Holocene (Yu et al., 2014). Because much of the ocean was 

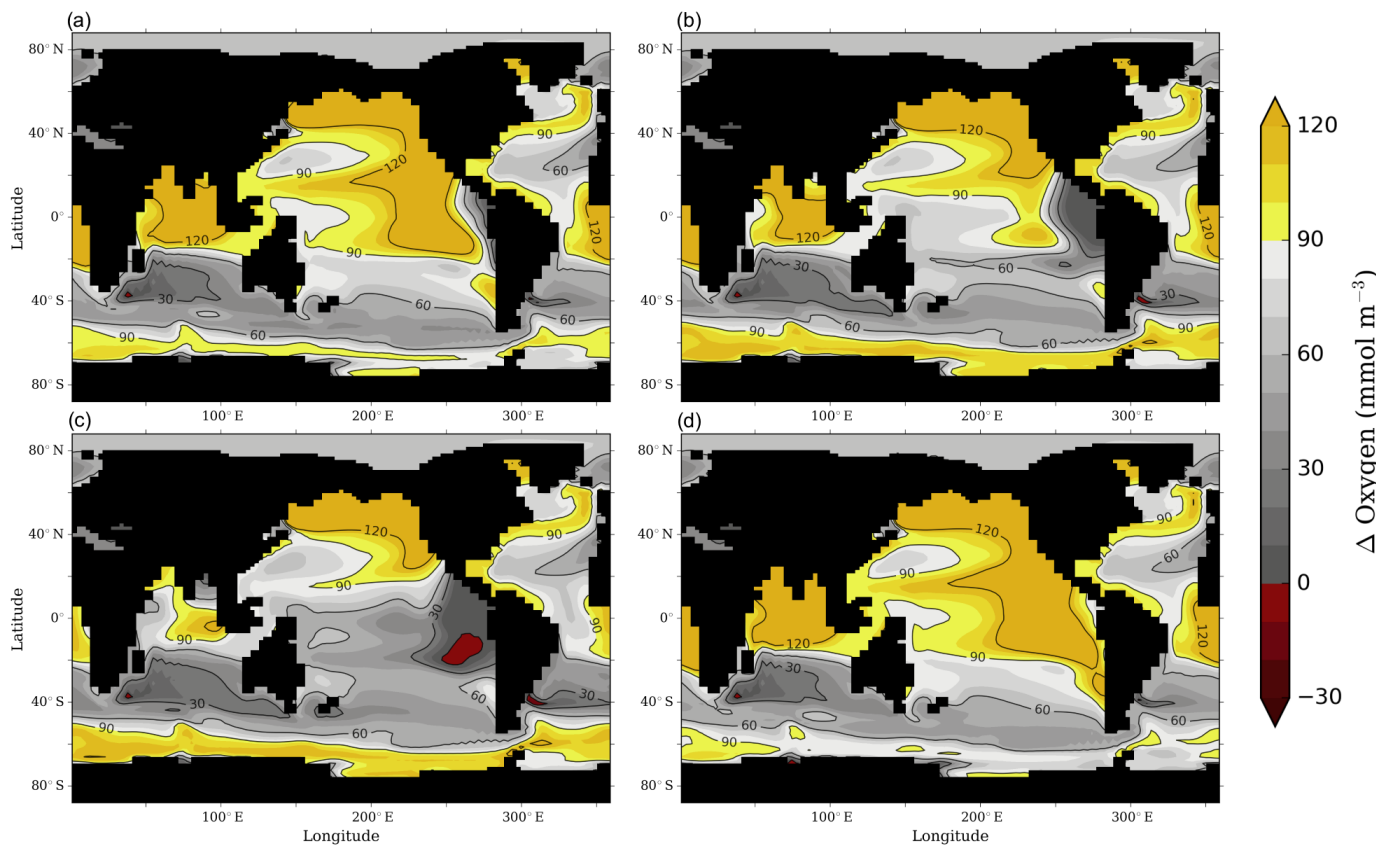

Figure 12. Change in oxygen concentration $\left(\mathrm{mmol} \mathrm{m}^{-3}\right)$ at $500 \mathrm{~m}$ between the LGM and PI for the experiments with modified biogeochemical formulations. (a) O-LGM $\mathrm{BGC}-\mathrm{O}-\mathrm{PI}$, (b) O-LGM $\mathrm{BGC}-\mathrm{O}-\mathrm{PI}$, (c) O-LGM pic $-\mathrm{O}$-PI and (d) O-LGM all $-\mathrm{O}$-PI. A depth of 500 m is representative of the depth at which the greatest extent of low-oxygen water exists in the simulated PI climate. It should be noted that the oxygen field for experiment $\mathrm{O}-\mathrm{LGM}_{\text {pic }}^{\mathrm{BGC}}$, whereby particulate inorganic carbon was set to zero, did not differ from the unmodified glacial experiment O-LGM and can therefore be used here as a reference to that simulation.

saturated for calcite in the O-LGM experiment, additional processes were required to shoal the depth at which calcite becomes unsaturated $\left(\Omega_{\mathrm{ca}}=1\right)$ and thereby reconcile proxy evidence.

One mechanism to reduce deep-ocean $\Omega_{\text {ca }}$ would be to reduce continental inputs of alkalinity at the LGM. However, the presence of glaciers, drier atmospheric conditions and the exposure of continental shelves due to lower sea level would have increased the supply of carbonates to the ocean (Gibbs and Kump, 1994; Riebe et al., 2004), thereby increasing ocean alkalinity and further deepening the carbonate saturation horizon. This mechanism has been largely refuted as having a significant effect on the glacial-interglacial difference in the carbon budget (Brovkin et al., 2007; Foster and Vance, 2006; Jones et al., 2002) and can therefore be ignored.

The individual biogeochemical modifications were also insufficient to reduce $\Omega_{\mathrm{ca}}$ to be consistent with palaeo evidence. However, combining all three modifications in experiment O-LGM $\mathrm{Ball}$ reduced $\Omega_{\mathrm{ca}}$ significantly (Fig. 11) and produced a globally averaged calcite saturation horizon at $2839 \mathrm{~m}$. Remarkably, our simulated PI to LGM changes in $\Omega_{\mathrm{ca}}$ are also consistent with palaeoproxy reconstructions in a regional sense. The calcite saturation horizon in the Pacific Ocean was deeper in experiment O-LGM $\mathrm{Lall}^{\mathrm{BGC}}$ relative to OPI but was shallower in the Atlantic Ocean and within the Atlantic and Indian sectors of the subantarctic zone. Similar changes are seen in the proxy record, with a deepening of less than $1000 \mathrm{~m}$ in the North Pacific and Southern Ocean at the LGM (Anderson et al., 2002; Catubig et al., 1998) and a shoaling in the Atlantic Ocean (Anderson et al., 2002).

An important caveat of this study, which cannot be ignored, is the exclusion of calcium carbonate $\left(\mathrm{CaCO}_{3}\right)$ burial within ocean sediments. Because this process is not included in the model, it is highly likely that the deepening of the calcite saturation horizon that occurred in the standard LGM experiment (O-LGM) was too extreme. $\mathrm{CaCO}_{3}$ burial lowers the alkalinity of the glacial ocean and is therefore a negative feedback mechanism that modulates changes in carbonate chemistry (see Sigman et al., 2010, for a review). If calcite saturation increases through the water column, as found in O-LGM, the burial of $\mathrm{CaCO}_{3}$ would increase and subsequently mitigate the rise in whole-ocean alkalinity, which in turn would reduce calcite saturation and the ability of the ocean to store carbon. By not taking this process into account, both the deepening of the calcite saturation horizon and the storage of carbon were overestimated in experiment O-LGM.

However, the same reasoning can be applied to the experiments with biogeochemical modifications. If the burial of $\mathrm{CaCO}_{3}$ was included in these experiments, the shoaling of the calcite saturation horizon would have been somewhat mitigated by decreased $\mathrm{CaCO}_{3}$ burial that increased ocean alkalinity (Archer and Maier-Reimer, 1994). Consequently, the shoaling that was observed in these experiments was likely 

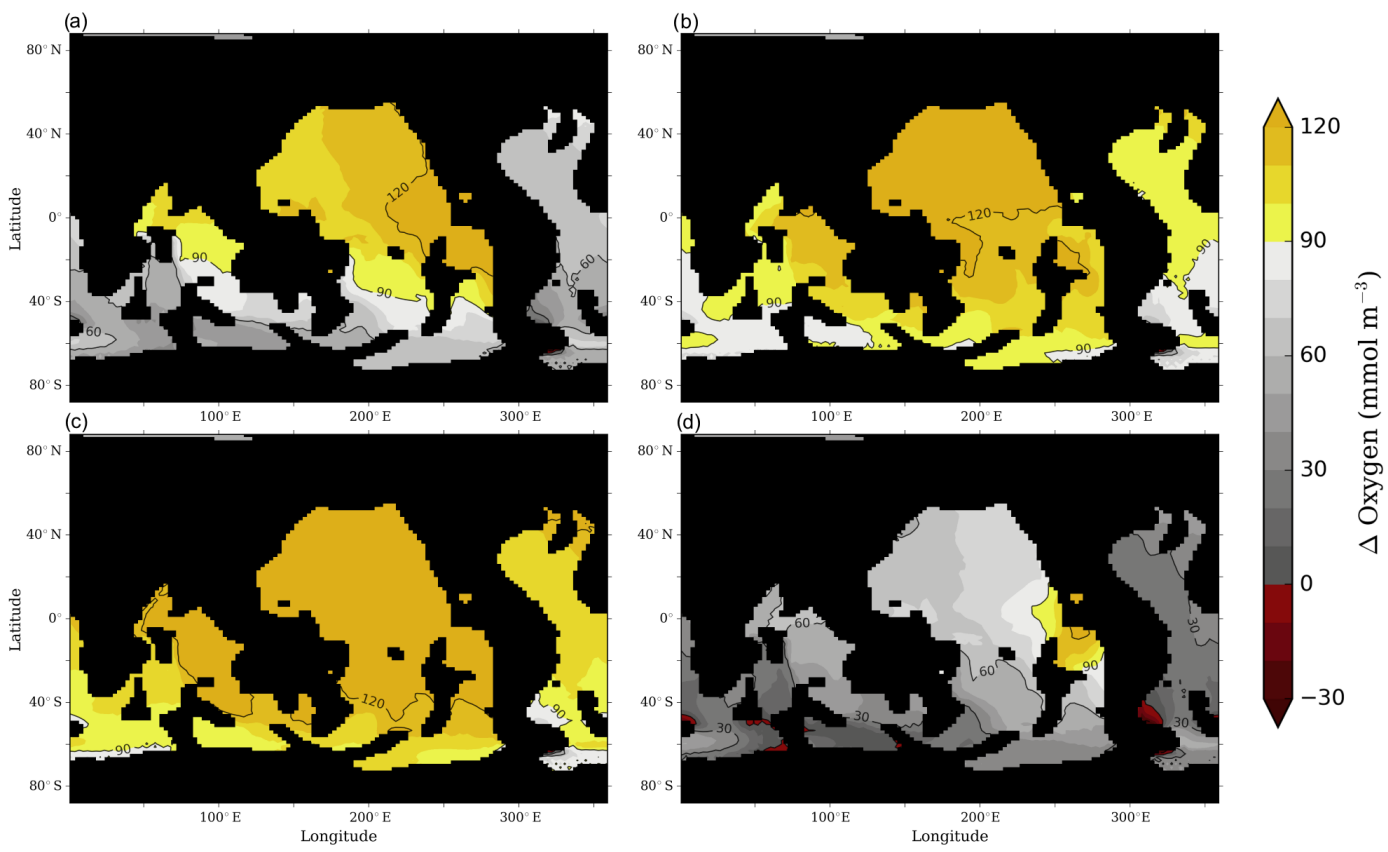

Figure 13. Change in oxygen concentration $\left(\mathrm{mmol} \mathrm{m}^{-3}\right)$ at $3500 \mathrm{~m}$ between the LGM and PI for the experiments with modified biogeo-

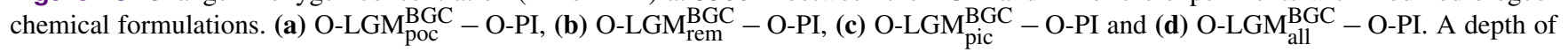
$3500 \mathrm{~m}$ is representative of the deep ocean. It should be noted that the oxygen field for experiment O-LGM pic , whereby particulate inorganic carbon was set to zero, did not differ from the unmodified glacial experiment O-LGM and can therefore be used here as a reference to that simulation.

exaggerated, just as the deepening observed in experiment $\mathrm{O}$ LGM was exaggerated. Again, this can be applied to changes in the carbon content of the ocean, as a shallower calcite saturation horizon would have reduced $\mathrm{CaCO}_{3}$ burial, thereby increasing whole-ocean alkalinity and the ocean's ability to take up carbon. This effect would have been particularly important for experiment $\mathrm{O}-\mathrm{LGM}_{\text {pic }}^{\mathrm{BGC}}$, where inorganic carbon export was eliminated. If whole-ocean alkalinity was able to respond to a decrease in $\mathrm{CaCO}_{3}$ rain, this would have amplified the carbon sequestration of experiment $\mathrm{O}-\mathrm{LGM}_{\text {pic }}^{\mathrm{BGC}}$. Therefore, the exclusion of $\mathrm{CaCO}_{3}$ burial in experiment $\mathrm{O}$ $\mathrm{LGM}_{\text {all }}^{\mathrm{BGC}}(\mathrm{O}-\mathrm{LGM})$ caused an exaggerated shoaling (deepening) of the calcite saturation horizon and an underestimated (overestimated) carbon content.

\subsubsection{Reconciling dissolved oxygen}

As discussed previously, the increase in oxygen concentrations of the upper ocean in experiment O-LGM is consistent with the current assemblage of proxy evidence. All experiments with modified biogeochemistry, including O$\mathrm{LGM}_{\text {all }}^{\mathrm{BGC}}$, had little effect on the upper-ocean oxygen concentration (Fig. 12; Table 3) and therefore did not compromise the agreement between simulated and proxy oxygen reconstructions.

Modifying ocean biogeochemistry did, however, have a large effect on the oxygen concentrations of the deep ocean
(Fig. 13). Increasing export production $\left(\mathrm{O}-\mathrm{LGM}_{\mathrm{poc}}^{\mathrm{BGC}}\right)$ and deepening the remineralisation depth $\left(\mathrm{O}-\mathrm{LGM}_{\mathrm{rem}}^{\mathrm{BGC}}\right)$ both reduced oxygen concentrations by 28 and $13 \mathrm{mmol} \mathrm{m}^{-3}$, respectively. The combination of these modifications (O$\mathrm{LGM}_{\mathrm{all}}^{\mathrm{BGC}}$ ) amplified their individual effects, so that deepocean oxygen was reduced by $63 \mathrm{mmol} \mathrm{m}^{-3}$ relative to OLGM. The increased sensitivity of deep-ocean oxygen to the combination of increased export production and a deeper remineralisation depth was also observed in the increase in the quantity of regenerated nutrients $\left(\mathrm{C}_{\mathrm{org}}\right)$ that resulted (Table 3). A greater proportion of regenerated nutrients relative to preformed nutrients at the LGM has been identified as a key driver of interior ocean deoxygenation (Jaccard and Galbraith, 2012; Sigman et al., 2010), and this process was captured in experiment O-LGMall .

While the combination of biogeochemical modifications $\left(\mathrm{O}-\mathrm{LGM}_{\mathrm{all}}^{\mathrm{BGC}}\right)$ did reduce deep-ocean oxygen towards the concentrations of the PI ocean in a number of areas (Fig. 13), by no means were global deep-ocean concentrations $\left(237 \mathrm{mmol} \mathrm{m}^{-3}\right)$ lower than those of O-PI $\left(180 \mathrm{mmol} \mathrm{m}^{-3}\right)$. The simulated oxygenation of the deep ocean remains in contrast to proxy records. However, this inconsistency may be resolved by addressing some key differences in physical and biogeochemical fields that evolved in our simulations. A key physical mechanism to reduce deepocean oxygen concentrations would include equivalent or 
slower formation rates of major ocean deep waters (as per Menviel et al., 2016) combined with an intensified coverage of sea ice in the region of their formation. The growth of sea ice and the formation rate of AABW were likely too strong in our LGM simulation (see Sects. 3.1.2 and 3.1.3), and we therefore suggest that a sluggish circulation is necessary for reducing deep-ocean oxygen. Key biogeochemical mechanisms include a further increase in global export production, and/or a different spatial pattern of export production, and/or increasing the injection of organic matter to deep water via further lengthening the remineralisation profile. The weakened biological pump in our LGM simulations contrasts with other studies (Galbraith and Jaccard, 2015; Schmittner and Somes, 2016) and indicates that export production may be underestimated by our simulations. The combination of a more sluggish deep-ocean circulation with an enhanced export of organics would significantly reduce the oxygen content of the deep ocean, while potentially further increasing carbon storage.

\section{Conclusions}

In this study we have shown that simulated physical changes in the ocean state during the climate of the Last Glacial Maximum are not sufficient to explain the 80-100 ppm drawdown of atmospheric $\mathrm{CO}_{2}$. Physical changes associated with the glacial climate, including an expanded sea ice field, increased solubility and a reorganisation of the global overturning circulation, were responsible for roughly $40 \mathrm{ppm}$ of $\mathrm{CO}_{2}$ drawdown. The effect of circulation on carbon storage was greatest at $28 \mathrm{ppm}$ and was associated with an expansion of southern source waters throughout the deep ocean. Thus, various biogeochemical modifications were necessary to fully explain the atmospheric drawdown of $\mathrm{CO}_{2}$ during the glacial period. The biogeochemical modifications explored in this study were (1) an increase in export production consistent with greater iron fertilisation, (2) a shift of remineralisation to the deep ocean consistent with cooler temperatures, and (3) a decrease in the production of particulate inorganic carbon consistent with cooler temperatures and increased delivery of silicate to lower latitudes. Together, these modifications increased the carbon content of the ocean and, combined with physical changes, were able to account for the loss of carbon from the atmosphere and land at the Last Glacial Maximum. Furthermore, their addition improved modelproxy agreement in the fields of export production, carbonate chemistry and dissolved oxygen. This study demonstrates that fundamental changes to ocean biogeochemical function are required to explain glacial-interglacial cycles.

\section{Data availability}

The model output produced during the experiments of this study is held by the Australian National Computational In- frastructure (NCI) data portal and is available for download at doi:10.4225/41/5859eeac6b473 (Buchanan, 2016).

Acknowledgements. We wish to thank Katsumi Matsumoto and Andreas Schmittner for their reviews that significantly improved the manuscript. Funding for this work was provided by the Australian Climate Change Science Program and CSIRO Wealth from Ocean Flagship. An award under the Merit Allocation Scheme on the NCI National Facility at the Australian National University ensured that numerical simulations could be undertaken. This research was also supported under the Australian Research Council's Special Research Initiative for the Antarctic Gateway Partnership (Project ID SR140300001). The authors wish to acknowledge the use of the Ferret program (http://ferret.pmel.noaa.gov/Ferret/) for the analysis undertaken in this work. The matplotlib package (Hunter, 2007), Iris and Cartopy packages (http://scitools.org.uk/), and cmocean package (Thyng et al., 2016) were all used for producing visualisations.

Edited by: A. Winguth

Reviewed by: K. Matsumoto and A. Schmittner

\section{References}

Abbey, E., Webster, J. M., and Beaman, R. J.: Geomorphology of submerged reefs on the shelf edge of the Great Barrier Reef: The influence of oscillating Pleistocene sea-levels, Mar. Geol., 288, 61-78, doi:10.1016/j.margeo.2011.08.006, 2011.

Adkins, J. F.: The role of deep ocean circulation in setting glacial climates, Paleoceanography, 28, 539-561, doi:10.1002/palo.20046, 2013.

Alder, J. R. and Hostetler, S. W.: Global climate simulations at 3000-year intervals for the last 21000 years with the GENMOM coupled atmosphere-ocean model, Clim. Past, 11, 449471, doi:10.5194/cp-11-449-2015, 2015.

Anderson, R. F., Chase, Z., Fleisher, M. Q., and Sachs, J.: The Southern Ocean's biological pump during the Last Glacial Maximum, Deep-Sea Res. Pt. II, 49, 1909-1938, 2002.

Anderson, R. F., Barker, S., Fleisher, M., Gersonde, R., Goldstein, S. L., Kuhn, G., Mortyn, P. G., Pahnke, K., and Sachs, J. P.: Biological response to millennial variability of dust and nutrient supply in the Subantarctic South Atlantic Ocean, Philos. T. R. Soc. A, 372, 20130054, doi:10.1098/rsta.2013.0054, 2014.

Annan, J. and Hargreaves, J.: A perspective on model-data surface temperature comparison at the Last Glacial Maximum, Quaternary Sci. Rev., 107, 1-10, doi:10.1016/j.quascirev.2014.09.019, 2015.

Annan, J. D. and Hargreaves, J. C.: A new global reconstruction of temperature changes at the Last Glacial Maximum, Clim. Past, 9, 367-376, doi:10.5194/cp-9-367-2013, 2013.

Archer, D. and Maier-Reimer, E.: Effect of deep-sea sedimentary calcite preservation on atmospheric $\mathrm{CO}_{2}$ concentration, Nature, 367, 260-263, doi:10.1038/367260a0, 1994.

Archer, D., Winguth, A., Lea, D., and Mahowald, N.: What caused the glacial/interglacial atmospheric $p \mathrm{CO}_{2}$ cycles?, Rev. Geophys., 38, 159-189, doi:10.1029/1999RG000066, 2000.

Ballantyne, A. P., Lavine, M., Crowley, T. J., Liu, J., and Baker, P. B.: Meta-analysis of tropical surface temperatures during 
the Last Glacial Maximum, Geophys. Res. Lett., 32, 1-4, doi:10.1029/2004GL021217, 2005.

Benz, V., Esper, O., Gersonde, R., Lamy, F., and Tiedemann, R.: Last Glacial Maximum sea surface temperature and sea-ice extent in the Pacific sector of the Southern Ocean, Quaternary Sci. Rev., 146, 216-237, doi:10.1016/j.quascirev.2016.06.006, 2016.

Bostock, H. C., Barrows, T. T., Carter, L., Chase, Z., Cortese, G., Dunbar, G. B., Ellwood, M., Hayward, B., Howard, W., Neil, H. L., Noble, T. L., Mackintosh, A., Moss, P. T., Moy, A. D., White, D., Williams, M. J. M., and Armand, L. K.: A review of the Australian-New Zealand sector of the Southern Ocean over the last $30 \mathrm{ka}$ (Aus-INTIMATE project), Quaternary Sci. Rev., 74, 35-57, doi:10.1016/j.quascirev.2012.07.018, 2013.

Boyle, E. A.: Cadmium and $\Delta^{13} \mathrm{C}$ Paleochemical Ocean Distributions During the Stage 2 Glacial Maximum, Annu. Rev. Earth Planet. Sc., 20, 245-287, doi:10.1146/annurev.ea.20.050192.001333, 1992.

Braconnot, P., Otto-Bliesner, B., Harrison, S., Joussaume, S., Peterchmitt, J.-Y., Abe-Ouchi, A., Crucifix, M., Driesschaert, E., Fichefet, Th., Hewitt, C. D., Kageyama, M., Kitoh, A., Laîné, A., Loutre, M.-F., Marti, O., Merkel, U., Ramstein, G., Valdes, P., Weber, S. L., Yu, Y., and Zhao, Y.: Results of PMIP2 coupled simulations of the Mid-Holocene and Last Glacial Maximum Part 1: experiments and large-scale features, Clim. Past, 3, 261277, doi:10.5194/cp-3-261-2007, 2007.

Bradtmiller, L. I., Anderson, R. F., Fleisher, M. Q., and Burckle, L. H.: Comparing glacial and Holocene opal fluxes in the Pacific sector of the Southern Ocean, Paleoceanography, 24, 1-20, doi:10.1029/2008PA001693, 2009.

Broecker, W. S.: Glacial to interglacial changes in ocean chemistry, Progress in Oceanography, 11, 151-197, doi:10.1016/00796611(82)90007-6, 1982.

Broecker, W. S. and Henderson, G. M.: The sequence of events surrounding termination II and their implications for the causes of glacial interglacial $\mathrm{CO}_{2}$ changes, Paleoceanography, 13, 352364, 1998.

Brovkin, V., Ganopolski, A., Archer, D., and Rahmstorf, S.: Lowering of glacial atmospheric $\mathrm{CO}_{2}$ in response to changes in oceanic circulation and marine biogeochemistry, Paleoceanography, 22, PA4202, doi:10.1029/2006PA001380, 2007.

Burckel, P., Waelbroeck, C., Luo, Y., Roche, D. M., Pichat, S., Jaccard, S. L., Gherardi, J., Govin, A., Lippold, J., and Thil, F.: Changes in the geometry and strength of the Atlantic meridional overturning circulation during the last glacial (20-50 ka), Clim. Past, 12, 2061-2075, doi:10.5194/cp-12-2061-2016, 2016.

Buchanan, P.: Simulations of glacial climate and ocean biogeochemistry with the CSIRO Mk3L v1.0, doi:10.4225/41/5859eeac6b473, 2016.

Cannariato, K. G. and Kennett, J. P.: Climatically related millennialscale fluctuations in strength of California margin oxygenminimum zone during the past $60 \mathrm{k} . \mathrm{y} .$, Geology, 27, 975-978, doi:10.1130/0091-7613(1999)027<0975:CRMSFI>2.3.CO;2, 1999.

Cartapanis, O., Tachikawa, K., and Bard, E.: Northeastern Pacific oxygen minimum zone variability over the past $70 \mathrm{kyr}$ : Impact of biological production and oceanic ventilation, Paleoceanography, 26, PA4208, doi:10.1029/2011PA002126, 2011.

Catubig, N. R., Archer, D. E., Francois, R., DeMenocal, P., Howard, W., and Yu, E.-F.: Global deep-sea burial rate of calcium car- bonate during the Last Glacial Maximum, Paleoceanography, 13, 298-310, doi:10.1029/98PA00609, 1998.

Chang, A. S., Pedersen, T. F., and Hendy, I. L.: Effects of productivity, glaciation, and ventilation on late Quaternary sedimentary redox and trace element accumulation on the Vancouver Island margin, western Canada, Paleoceanography, 29, 730-746, doi:10.1002/2013PA002581, 2014.

Chang, A. S., Pichevin, L., Pedersen, T. F., Gray, V., and Ganeshram, R.: New insights into productivity and redoxcontrolled trace element ( $\mathrm{Ag}, \mathrm{Cd}, \mathrm{Re}$, and $\mathrm{Mo}$ ) accumulation in a $55 \mathrm{kyr}$ long sediment record from Guaymas Basin, Gulf of California, Paleoceanography, 30, 77-94, doi:10.1002/2014PA002681, 2015.

Chase, Z., Anderson, R. F., and Fleisher, M. Q.: Evidence from authigenic uranium for increased productivity of the glacial Subantarctic Ocean, Paleoceanography, 16, 468-478, doi:10.1029/2000PA000542, 2001.

Chase, Z., Anderson, R. F., Fleisher, M. Q., and Kubik, P. W.: Accumulation of biogenic and lithogenic material in the Pacific sector of the Southern Ocean during the past 40,000 years, Deep-Sea Res. Pt. II, 50, 799-832, doi:10.1016/S0967-0645(02)00595-7, 2003.

Ciais, P., Tagliabue, A., Cuntz, M., Bopp, L., Scholze, M., Hoffmann, G., Lourantou, A., Harrison, S. P., Prentice, I. C., Kelley, D. I., Koven, C., and Piao, S. L.: Large inert carbon pool in the terrestrial biosphere during the Last Glacial Maximum, Nat. Geosci., 5, 74-79, doi:10.1038/ngeo1324, 2011.

Clementson, L. A., Parslow, J. S., Griffiths, F. B., Lyne, V. D., Mackey, D. J., Harris, G. P., Mckenzie, D. C., Bonham, P. I., Rathbone, C. A., and Rintoul, S.: Controls on phytoplankton production in the Australasian sector of the subtropical convergence, Deep-Sea Res. Pt. I, 45, 1627-1661, doi:10.1016/S09670637(98)00035-1, 1998.

Collins, L. G., Pike, J., Allen, C. S., and Hodgson, D. A.: Highresolution reconstruction of southwest Atlantic sea-ice and its role in the carbon cycle during marine isotope stages 3 and 2, Paleoceanography, 27, 1-17, doi:10.1029/2011PA002264, 2012.

Costa, K. M., McManus, J. F., Anderson, R. F., Ren, H., Sigman, D. M., Winckler, G., Fleisher, M. Q., Marcantonio, F., and Ravelo, A. C.: No iron fertilization in the equatorial Pacific Ocean during the last ice age, Nature, 529, 519-522, doi:10.1038/nature16453, 2016.

Crusius, J., Pedersen, T. F., Kienast, S., Keigwin, L., and Labeyrie, L.: Influence of northwest Pacific productivity on North Pacific Intermediate Water oxygen concentrations during the Bolling-Allerod interval (14.7-12.9 ka), Geology, 32, 633-636, doi:10.1130/G20508.1, 2004.

Curran, M. A. J., van Ommen, T. D., Morgan, V. I., Phillips, K. L., and Palmer, A. S.: Ice Core Evidence for Antarctic Sea Ice Decline Since the 1950s, Science, 302, 1203-1206, doi:10.1126/science.1087888, 2003.

Curry, W. B. and Oppo, D. W.: Glacial water mass geometry and the distribution of $\delta^{13} \mathrm{C}$ of $\Sigma \mathrm{CO}_{2}$ in the western Atlantic Ocean, Paleoceanography, 20, PA1017, doi:10.1029/2004PA001021, 2005.

de la Fuente, M., Skinner, L., Calvo, E., Pelejero, C., and Cacho, I.: Increased reservoir ages and poorly ventilated deep waters inferred in the glacial Eastern Equatorial Pacific, Nat. Commun., 6, 7420, doi:10.1038/ncomms8420, 2015. 
De Vernal, A., Eynaud, F., Henry, M., Hillaire-Marcel, C., Londeix, L., Mangin, S., Matthiessen, J., Marret, F., Radi, T., Rochon, A., Solignac, S., and Turon, J. L.: Reconstruction of seasurface conditions at middle to high latitudes of the Northern Hemisphere during the Last Glacial Maximum (LGM) based on dinoflagellate cyst assemblages, Quaternary Sci. Rev., 24, 897924, doi:10.1016/j.quascirev.2004.06.014, 2005.

Dean, W. E.: Sediment geochemical records of productivity and oxygen depletion along the margin of western North America during the past 60,000 years: teleconnections with Greenland Ice and the Cariaco Basin, Quaternary Sci. Rev., 26, 98-114, doi:10.1016/j.quascirev.2006.08.006, 2007.

Dubois, N., Kienast, M., Kienast, S. S., and Timmermann, A.: Millennial-scale Atlantic/East Pacific sea surface temperature linkages during the last 100,000 years, Earth Planet. Sc. Lett., 396, 134-142, doi:10.1016/j.epsl.2014.04.008, 2014.

Duplessy, J. C., Shackleton, N. J., Fairbanks, R. G., Labeyrie, L., Oppo, D., and Kallel, N.: Deepwater source variations during the last climatic cycle and their impact on the global deepwater circulation, Paleoceanography, 3, 343-360, doi:10.1029/PA003i003p00343, 1988.

Duteil, O., Koeve, W., Oschlies, A., Aumont, O., Bianchi, D., Bopp, L., Galbraith, E., Matear, R., Moore, J. K., Sarmiento, J. L., and Segschneider, J.: Preformed and regenerated phosphate in ocean general circulation models: can right total concentrations be wrong?, Biogeosciences, 9, 1797-1807, doi:10.5194/bg-91797-2012, 2012.

Elderfield, H. and Rickaby, R.: Oceanic Cd / P ratio and nutrient utilization in the glacial Southern Ocean, Nature, 405, 305-10, doi:10.1038/35012507, 2000.

Emiliani, C.: Isotopic Paleotemperatures, Science, 154, 851-857, 1966.

Eppley, R. W.: Temperature and phytoplankton growth in the sea, Fish. B.-NOAA, 70, 1063-1085, 1972.

Ferrari, R., Jansen, M. F., Adkins, J. F., Burke, A., Stewart, A. L., and Thompson, A. F.: Antarctic sea ice control on ocean circulation in present and glacial climates, P. Natl. Acad. Sci. USA, 111, 8753-8758, doi:10.1073/pnas.1323922111, 2014.

Foster, G. L. and Vance, D.: Negligible glacial-interglacial variation in continental chemical weathering rates, Nature, 444, 918-921, doi:10.1038/nature05365, 2006.

Francois, R., Altabet, M. A., Yu, E.-F. F., Sigman, D. M., Bacon, M. P., Frank, M., Bohrmann, G., Bareille, G., and Labeyrie, L. D.: Contribution of Southern Ocean surface-water stratification to low atmospheric $\mathrm{CO}_{2}$ concentrations during the last glacial period, Nature, 389, 929-935, doi:10.1038/40073, 1997.

Frank, M., Gersonde, R., van der Loeff, M. R., Bohrmann, G., Nürnberg, C. C., Kubik, P. W., Suter, M., and Mangini, A.: Similar glacial and interglacial export bioproductivity in the Atlantic Sector of the Southern Ocean: Multiproxy evidence and implications for glacial atmospheric $\mathrm{CO}_{2}$, Paleoceanography, 15, 642658, doi:10.1029/2000PA000497, 2000.

Galbraith, E. D. and Jaccard, S. L.: Deglacial weakening of the oceanic soft tissue pump: global constraints from sedimentary nitrogen isotopes and oxygenation proxies, Quaternary Sci. Rev., 109, 38-48, doi:10.1016/j.quascirev.2014.11.012, 2015.

Galbraith, E. D., Kienast, M., Pedersen, T. F., and Calvert, S. E.: Glacial-interglacial modulation of the marine nitrogen cycle by high-latitude $\mathrm{O}_{2}$ supply to the global thermocline, Paleoceanography, 19, 1-12, doi:10.1029/2003PA001000, 2004.

Garcia, H. E.: On the variability of dissolved oxygen and apparent oxygen utilization content for the upper world ocean: 1955 to 1998, Geophys. Res. Lett., 32, L09604, doi:10.1029/2004GL022286, 2005.

Garcia, H. E., Locarnini, R. A., Boyer, T. P., Antonov, J. I., Mishonov, A. V., Baranova, O. K., Zweng, M. M., Reagan, J. R., and Johnson, D. R.: World Ocean Atlas 2013. Vol. 3: Dissolved Oxygen, Apparent Oxygen Utilization, and Oxygen Saturation, edited by: Levitus, S., A. Mishonov, Technical Ed., Tech. rep., NOAA Atlas NESDIS 75, 2013.

Gebbie, G.: How much did Glacial North Atlantic Water shoal?, Paleoceanography, 29, 190-209, doi:10.1002/2013PA002557, 2014.

Gersonde, R., Crosta, X., Abelmann, A., and Armand, L.: Sea-surface temperature and sea ice distribution of the Southern Ocean at the EPILOG Last Glacial Maximum - A circum-Antarctic view based on siliceous microfossil records, Quaternary Sci. Rev., 24, 869-896, doi:10.1016/j.quascirev.2004.07.015, 2005.

Gibbs, M. T. and Kump, L. R.: Global Chemical Erosion During the Last Glacial Maximum and the Present - Sensitivity To Changes in Lithology and Hydrology, Paleoceanography, 9, 529543, doi:10.1029/94pa01009, 1994.

Gloersen, P., Campbell, W. J., Cavalieri, D. J., Cosimo, J. C., Parkinson, C. L., and Zwalley, H. J.: Satellite passive microwave observations and analysis of Arctic and Antarctic sea ice, 1978-1987, Ann. Glaciol., 17, 149-154, doi:10.1016/0021-9169(95)90010$1,1993$.

Gottschalk, J., Skinner, L. C., Lippold, J., Vogel, H., Frank, N., Jaccard, S. L., and Waelbroeck, C.: Biological and physical controls in the Southern Ocean on past millennial-scale atmospheric $\mathrm{CO}_{2}$ changes, Nat. Commun., 7, 11539, doi:10.1038/ncomms11539, 2016.

Grootes, P. M. and Stuiver, M.: Oxygen 18/16 variability in Greenland snow and ice with $10^{3}$ - to $10^{5}$-year time resolution, J. Geophys. Res., 102, 26455-26470, doi:10.1029/97JC00880, 1997.

Hain, M. P., Sigman, D. M., and Haug, G. H.: Carbon dioxide effects of Antarctic stratification, North Atlantic Intermediate Water formation, and subantarctic nutrient drawdown during the last ice age: Diagnosis and synthesis in a geochemical box model, Global Biogeochem. Cy., 24, 1-20, doi:10.1029/2010GB003790, 2010.

Herguera, J. C.: Last glacial paleoproductivity patterns in the eastern equatorial Pacific: benthic foraminifera records, Mar. Micropaleontol., 40, 259-275, 2000.

Ho, S. L. and Laepple, T.: Glacial cooling as inferred from marine temperature proxies TEXH86 and UK37, Earth Planet. Sc. Lett., 409, 15-22, doi:10.1016/j.epsl.2014.10.033, 2015.

Hoegh-Guldberg, O., Mumby, P. J., Hooten, A. J., Steneck, R. S., Greenfield, P., Gomez, E., Harvell, C. D., Sale, P. F., Edwards, A. J., Caldeira, K., Knowlton, N., Eakin, C. M., Iglesias-Prieto, R., Muthiga, N., Bradbury, R. H., Dubi, A., and Hatziolos, M. E.: Coral Reefs Under Rapid Climate Change and Ocean Acidification, Science, 318, 1737-1742, doi:10.1126/science.1152509, 2007.

Hoogakker, B. A. A., Elderfield, H., Schmiedl, G., McCave, I. N., and Rickaby, R. E. M.: Glacial-interglacial changes in bottom- 
water oxygen content on the Portuguese margin, Nat. Geosci., 8, 2-5, doi:10.1038/ngeo2317, 2014.

Howe, J. N. W., Piotrowski, A. M., Noble, T. L., Mulitza, S., Chiessi, C. M., and Bayon, G.: North Atlantic Deep Water Production during the Last Glacial Maximum, Nat. Commun., 7, 11765, doi:10.1038/ncomms11765, 2016.

Hunter, J. D.: Matplotlib: A 2-D graphics environment, Computing In Science \& Engineering, 9, 90-95, 2007.

Ikehara, K.: Late Quaternary seasonal sea-ice history of the northeastern Japan Sea, J. Oceanogr., 59, 585-593, doi:10.1023/B:JOCE.0000009588.49944.3d, 2003.

Ishizaki, Y., Ohkushi, K., Ito, T., and Kawahata, H.: Abrupt changes of intermediate-water oxygen in the northwestern Pacific during the last $27 \mathrm{kyr}$, Geo-Mar. Lett., 29, 125-131, doi:10.1007/s00367-008-0128-0, 2009.

Jaccard, S., Galbraith, E., Frölicher, T., and Gruber, N.: Ocean (De)oxygenation Across the Last Deglaciation: Insights for the Future, Oceanography, 27, 26-35, doi:10.5670/oceanog.2014.05, 2014.

Jaccard, S. L. and Galbraith, E. D.: Large climate-driven changes of oceanic oxygen concentrations during the last deglaciation, Nat. Geosci., 5, 151-156, doi:10.1038/ngeo1352, 2012.

Jaccard, S. L., Haug, G. H., Sigman, D. M., Pedersen, T. F., Thierstein, H. R., and Röhl, U.: Glacial/interglacial changes in subarctic north pacific stratification, Science, 308, 1003-1006, doi:10.1126/science.1108696, 2005.

Jaccard, S. L., Hayes, C. T., Hodell, D. A., Anderson, R. F., Sigman, D. M., and Haug, G. H.: Two modes of change in Southern Ocean productivity over the past million years, Science, 339, 1419-1423, 2013.

Jaccard, S. L., Galbraith, E. D., Martínez-García, A., and Anderson, R. F.: Covariation of deep Southern Ocean oxygenation and atmospheric $\mathrm{CO}_{2}$ through the last ice age, Nature, 530, 207-10, doi:10.1038/nature16514, 2016.

Jones, I., Munhoven, G., Tranter, M., Huybrechts, P., and Sharp, M.: Modelled glacial and non-glacial $\mathrm{HCO}_{3}, \mathrm{Si}$ and Ge fluxes since the LGM: little potential for impact on atmospheric $\mathrm{CO}_{2}$ concentrations and a potential proxy of continental chemical erosion, the marine Ge/Si ratio, Global Planet. Change, 33, 139153, doi:10.1016/S0921-8181(02)00067-X, 2002.

Jouzel, J., Lorius, C., Petit, J. R., Genthon, C., Barkov, N. I., Kotlyakov, V. M., and Petrov, V. M.: Vostok ice core: a continuous isotope temperature record over the last climatic cycle (160,000 years), Nature, 329, 403-408, doi:10.1038/329403a0, 1987.

Keigwin, L. D.: Radiocarbon and stable isotope constraints on Last Glacial Maximum and Younger Dryas ventilation in the western North Atlantic, Paleoceanography, 19, 1-15, doi:10.1029/2004PA001029, 2004.

Key, R. M., Kozyr, A., Sabine, C. L., Lee, K., Wanninkhof, R., Bullister, J. L., Feely, R. A., Millero, F. J., Mordy, C., and Peng, T.-H.: A global ocean carbon climatology: Results from Global Data Analysis Project (GLODAP), Global Biogeochem. Cy., 18, GB4031, doi:10.1029/2004GB002247, 2004.

Kohfeld, K. E. and Chase, Z.: Controls on deglacial changes in biogenic fluxes in the North Pacific Ocean, Quaternary Sci. Rev., 30, 3350-3363, doi:10.1016/j.quascirev.2011.08.007, 2011.

Kohfeld, K. E. and Ridgwell, A.: Glacial-interglacial variability in atmospheric $\mathrm{CO}_{2}$, in: Surface Ocean - Lower Atmo- sphere Processes, edited by: Le Quéré, C. and Saltzman, E. S., 251-286, American Geophysical Union, Washington, D.C., doi:10.1029/2008GM000845, 2009.

Kohfeld, K. E., Le Quéré, C., Harrison, S. P., and Anderson, R. F.: Role of marine biology in glacial-interglacial $\mathrm{CO}_{2}$ cycles, Science, 308, 74-78, doi:10.1126/science.1105375, 2005.

Kucera, M., Weinelt, M., Kiefer, T., Pflaumann, U., Hayes, A., Weinelt, M., Chen, M. T., Mix, A. C., Barrows, T. T., Cortijo, E., Duprat, J., Juggins, S., and Waelbroeck, C.: Reconstruction of sea-surface temperatures from assemblages of planktonic foraminifera: Multi-technique approach based on geographically constrained calibration data sets and its application to glacial Atlantic and Pacific Oceans, Quaternary Sci. Rev., 24, 951-998, doi:10.1016/j.quascirev.2004.07.014, 2005.

Kumar, N., Anderson, R. F., Mortlock, R. A., Froelich, P. N., Kubik, P., Dittrich-Hannen, B., and Suter, M.: Increased biological productivity and export production in the glacial Southern Ocean, Nature, 378, 675-680, 1995.

Kurahashi-Nakamura, T., Abe-Ouchi, A., Yamanaka, Y., and Misumi, K.: Compound effects of Antarctic sea ice on atmospheric $p \mathrm{CO}_{2}$ change during glacial-interglacial cycle, Geophys. Res. Lett., 34, 1-5, doi:10.1029/2007GL030898, 2007.

Lamy, F., Gersonde, R., Winckler, G., Esper, O., Jaeschke, A., Kuhn, G., Ullermann, J., Martinez-Garcia, A., Lambert, F., and Kilian, R.: Increased dust deposition in the Pacific Southern Ocean during glacial periods, Science, 343, 403-407, doi:10.1126/science.1245424, 2014.

Leduc, G., Schneider, R., Kim, J. H., and Lohmann, G.: Holocene and Eemian sea surface temperature trends as revealed by alkenone and $\mathrm{Mg} / \mathrm{Ca}$ paleothermometry, Quaternary Sci. Rev., 29, 989-1004, doi:10.1016/j.quascirev.2010.01.004, 2010.

Levitus, S.: World Ocean Database, Vol. 13, US Department of Commerce, National Oceanic and Atmosphere Agency, 2001.

Loubere, P., Richaud, M., and Mireles, S.: Variability in tropical thermocline nutrient chemistry on the glacial/interglacial timescale, Deep-Sea Res. Pt. II, 54, 747-761, doi:10.1016/j.dsr2.2007.01.005, 2007.

Lynch-Stieglitz, J., Ito, T., and Michel, E.: Antarctic density stratification and the strength of the circumpolar current during the Last Glacial Maximum, Paleoceanography, 31, 539-552, doi:10.1002/2015PA002915, 2016.

Marchitto, T. M. and Broecker, W. S.: Deep water mass geometry in the glacial Atlantic Ocean: A review of constraints from the paleonutrient proxy $\mathrm{Cd} / \mathrm{Ca}$, Geochem. Geophy. Geosys., 7, Q12003, doi:10.1029/2006GC001323, 2006.

Marinov, I., Gnanadesikan, A., Toggweiler, J. R., and Sarmiento, J. L.: The Southern Ocean biogeochemical divide, Nature, 441, 964-967, doi:10.1038/nature04883, 2006.

Martin, J. H.: Glacial-interglacial $\mathrm{CO}_{2}$ change: the iron hypothesis, Paleoceanography, 5, 1-13, 1990.

Martinez, P., Lamy, F., Robinson, R. R., Pichevin, L., and Billy, I.: Atypical $\delta^{15} \mathrm{~N}$ variations at the southern boundary of the East Pacific oxygen minimum zone over the last $50 \mathrm{ka}$, Quaternary Sci. Rev., 25, 3017-3028, doi:10.1016/j.quascirev.2006.04.009, 2006.

Martinez-Garcia, A., Sigman, D. M., Ren, H., Anderson, R. F., Straub, M., Hodell, D. A., Jaccard, S. L., Eglinton, T. I., and Haug, G. H.: Iron Fertilization of the Subantarctic 
Ocean During the Last Ice Age, Science, 343, 1347-1350, doi:10.1126/science.1246848, 2014.

Matear, R. J. and Lenton, A.: Quantifying the impact of ocean acidification on our future climate, Biogeosciences, 11, 3965-3983, doi:10.5194/bg-11-3965-2014, 2014.

Matsumoto, K.: Biology-mediated temperature control on atmospheric $p \mathrm{CO}_{2}$ and ocean biogeochemistry, Geophys. Res. Lett., 34, L20605, doi:10.1029/2007GL031301, 2007.

Matsumoto, K., Sarmiento, J. L., and Brzezinski, M. A.: Silicic acid leakage from the Southern Ocean: A possible explanation for glacial atmospheric $p \mathrm{CO}_{2}$, Global Biogeochem. Cy., 16, 5-15-23, doi:10.1029/2001GB001442, 2002.

McKay, C. L., Groeneveld, J., Filipsson, H. L., Gallego-Torres, D., Whitehouse, M. J., Toyofuku, T., and Romero, O. E.: A comparison of benthic foraminiferal $\mathrm{Mn} / \mathrm{Ca}$ and sedimentary $\mathrm{Mn} / \mathrm{Al}$ as proxies of relative bottom-water oxygenation in the low-latitude NE Atlantic upwelling system, Biogeosciences, 12, 5415-5428, doi:10.5194/bg-12-5415-2015, 2015.

McManus, J. F., Francois, R., Gherardi, J.-M., Keigwin, L. D., and Brown-Leger, S.: Collapse and rapid resumption of Atlantic meridional circulation linked to deglacial climate changes, Nature, 428, 834-837, doi:10.1038/nature02494, 2004.

Menviel, L., Joos, F., and Ritz, S. P.: Simulating atmospheric $\mathrm{CO}_{2},{ }^{13} \mathrm{C}$ and the marine carbon cycle during the Last Glacial-Interglacial cycle: Possible role for a deepening of the mean remineralization depth and an increase in the oceanic nutrient inventory, Quaternary Sci. Rev., 56, 46-68, doi:10.1016/j.quascirev.2012.09.012, 2012.

Menviel, L., Yu, J., Joos, F., Mouchet, A., Meissner, K. J., and England, M. H.: Poorly ventilated deep ocean at the Last Glacial Maximum inferred from carbon isotopes: a data-model comparison study, Paleoceanography, 31, doi:10.1002/2016PA003024, online first, 2016.

Mortlock, R. A., Charles, C. D., Froelich, P. N., Zibello, M. A., Saltzman, J., Hays, J. D., and Burckle, L. H.: Evidence for lower productivity in the Antarctic Ocean during the last glaciation, Nature, 351, 220-223, doi:10.1038/351220a0, 1991.

Muglia, J. and Schmittner, A.: Glacial Atlantic overturning increased by wind stress in climate models, Geophys. Res. Lett., 42, 1-8, doi:10.1002/2015GL064583, 2015.

Müller, J., Massé, G., Stein, R., and Belt, S. T.: Variability of seaice conditions in the Fram Strait over the past 30,000 years, Nat. Geosci., 2, 772-776, doi:10.1038/ngeo665, 2009.

Muratli, J. M., Chase, Z., Mix, A. C., and McManus, J.: Increased glacial-age ventilation of the Chilean margin by Antarctic Intermediate Water, Nat. Geosci., 3, 23-26, doi:10.1038/ngeo715, 2010 .

Murgese, D. S., De Deckker, P., Spooner, M. I., and Young, M.: A 35,000 year record of changes in the eastern Indian Ocean offshore Sumatra, Palaeogeogr. Palaeocl., 265, 195-213, doi:10.1016/j.palaeo.2008.06.001, 2008.

Nameroff, T. J., Calvert, S. E., and Murray, J. W.: Glacialinterglacial variability in the eastern tropical North Pacific oxygen minimum zone recorded by redox-sensitive trace metals, $\mathrm{Pa}$ leoceanography, 19, 1-19, doi:10.1029/2003PA000912, 2004.

Ninnemann, U. S. and Charles, C. D.: Regional differences in Quaternary Subantarctic nutrient cycling: Link to intermediate and deep water ventilation, Paleoceanography, 12, 560-567, 1997.
Nürnberg, C. C., Bohrmann, G., Schlüter, M., and Frank, M.: Barium accumulation in the Atlantic sector of the Southern Ocean: Results From 190,000-year records, Paleoceanography, 12, 594 603, doi:10.1029/97PA01130, 1997.

Nürnberg, D. and Tiedemann, R.: Environmental change in the Sea of Okhotsk during the last 1.1 million years, Paleoceanography, 19, 1-23, doi:10.1029/2004PA001023, 2004.

Ohkushi, K., Kennett, J. P., Zeleski, C. M., Moffitt, S. E., Hill, T. M., Robert, C., Beaufort, L., and Behl, R. J.: Quantified intermediate water oxygenation history of the NE Pacific: A new benthic foraminiferal record from Santa Barbara basin, Paleoceanography, 28, 453-467, doi:10.1002/palo.20043, 2013.

Oliver, K. I. C., Hoogakker, B. A. A., Crowhurst, S., Henderson, G. M., Rickaby, R. E. M., Edwards, N. R., and Elderfield, H.: A synthesis of marine sediment core $\delta^{13} \mathrm{C}$ data over the last 150000 years, Clim. Past, 6, 645-673, doi:10.5194/cp-6-6452010, 2010.

Ortiz, J. D., O'Connell, S. B., DelViscio, J., Dean, W., Carriquiry, J. D., Marchitto, T., Zheng, Y., and van Geen, A.: Enhanced marine productivity off western North America during warm climate intervals of the past $52 \mathrm{k} . \mathrm{y}$, Geology, 32, 521-524, doi:10.1130/G20234.1, 2004.

Otto-Bliesner, B. L., Hewitt, C. D., Marchitto, T. M., Brady, E. Abe-Ouchi, A., Crucifix, M., Murakami, S., and Weber, S. L.: Last Glacial Maximum ocean thermohaline circulation: PMIP2 model intercomparisons and data constraints, Geophys. Res. Lett., 34, 1-6, doi:10.1029/2007GL029475, 2007.

Otto-Bliesner, B. L., Schneider, R., Brady, E. C., Kucera, M., AbeOuchi, A., Bard, E., Braconnot, P., Crucifix, M., Hewitt, C. D., Kageyama, M., Marti, O., Paul, A., Rosell-Melé, A., Waelbroeck, C., Weber, S. L., Weinelt, M., and Yu, Y.: A comparison of PMIP2 model simulations and the MARGO proxy reconstruction for tropical sea surface temperatures at last glacial maximum, Clim. Dynam., 32, 799-815, doi:10.1007/s00382-0080509-0, 2009.

Parrenin, F., Masson-Delmotte, V., Köhler, P., Raynaud, D., Paillard, D., Schwander, J., Barbante, C., Landais, A., Wegner, A., and Jouzel, J.: Synchronous change of atmospheric $\mathrm{CO}_{2}$ and Antarctic temperature during the last deglacial warming, Science, 339, 1060-1063, doi:10.1126/science.1226368, 2013.

Petit, R. J., Raynaud, D., Basile, I., Chappellaz, J., Ritz, C., Delmotte, M., Legrand, M., Lorius, C., and Pe, L.: Climate and atmospheric history of the past 420,000 years from the Vostok ice core, Antarctica, Nature, 399, 429-413, doi:10.1038/20859, 1999.

Pflaumann, U., Sarnthein, M., Chapman, M., D’Abreu, L., Funnell, B., Huels, M., Kiefer, T., Maslin, M., Schulz, H., Swallow, J., van Kreveld, S., Vautravers, M., Vogelsang, E., and Weinelt, M.: Glacial North Atlantic: sea-surface conditions reconstructed by GLAMAP 2000, Paleoceanography, 18, 1065 , doi:10.1029/2002PA000774, 2003.

Phipps, S. J., Rotstayn, L. D., Gordon, H. B., Roberts, J. L., Hirst, A. C., and Budd, W. F.: The CSIRO Mk3L climate system model version 1.0 - Part 1: Description and evaluation, Geosci. Model Dev., 4, 483-509, doi:10.5194/gmd-4-483-2011, 2011.

Phipps, S. J., Rotstayn, L. D., Gordon, H. B., Roberts, J. L., Hirst, A. C., and Budd, W. F.: The CSIRO Mk3L climate system model version 1.0 - Part 2: Response to external forcings, Geosci. Model Dev., 5, 649-682, doi:10.5194/gmd-5-649-2012, 2012. 
Phipps, S. J., Mcgregor, H. V., Gergis, J., Gallant, A. J. E., Neukom, R., Stevenson, S., Ackerley, D., Brown, J. R., Fischer, M. J., and Van Ommen, T. D.: Paleoclimate data-model comparison and the role of climate forcings over the past 1500 years, J. Climate, 26, 6915-6936, doi:10.1175/JCLI-D-12-00108.1, 2013.

Pride, C., Thunell, R., Sigman, D. M., Keigwin, L. D., Altabet, M. A., and Tappa, E.: Nitrogen isotopic variations in the Gulf of California since the last deglaciation: Response to global climate change, Paleoceanography, 14, 397-409, 1999.

Reichart, G. J., Lourens, L. J., and Zachariasse, W. J.: Temporal variability in the northern Arabian Sea oxygen minimum zone (OMZ) during the last 225,000 years, Paleoceanography, 13, 607, doi:10.1029/98PA02203, 1998.

Riebe, C. S., Kirchner, J. W., and Finkel, R. C.: Erosional and climatic effects on long-term chemical weathering rates in granitic landscapes spanning diverse climate regimes, Earth Planet. Sc. Lett., 224, 547-562, doi:10.1016/j.epsl.2004.05.019, 2004.

Riethdorf, J.-R., Nürnberg, D., Max, L., Tiedemann, R., Gorbarenko, S. A., and Malakhov, M. I.: Millennial-scale variability of marine productivity and terrigenous matter supply in the western Bering Sea over the past $180 \mathrm{kyr}$, Clim. Past, 9, 1345-1373, doi:10.5194/cp-9-1345-2013, 2013.

Rivkin, R. B. and Legendre, L.: Biogenic carbon cycling in the upper ocean: effects of microbial respiration, Science (New York, N.Y.), 291, 2398-2400, doi:10.1126/science.291.5512.2398, 2001.

Sakamoto, T., Ikehara, M., Aoki, K., Iijima, K., Kimura, N., Nakatsuka, T., and Wakatsuchi, M.: Ice-rafted debris (IRD)based sea-ice expansion events during the past 100 kyrs in the Okhotsk Sea, Deep-Sea Res. Pt. II, 52, 2275-2301, doi:10.1016/j.dsr2.2005.08.007, 2005.

Salvatteci, R., Gutierrez, D., Sifeddine, A., Ortlieb, L., Druffel, E., Boussafir, M., and Schneider, R.: Centennial to millennial-scale changes in oxygenation and productivity in the Eastern Tropical South Pacific during the last 25,000 years, Quaternary Sci. Rev., 131, 102-117, doi:10.1016/j.quascirev.2015.10.044, 2016.

Sarkar, A., Bhattacharya, S., and Sarin, M.: Geochemical evidence for anoxic deep water in the Arabian Sea during the last glaciation, Geochim. Cosmochim. Ac., 57, 1009-1016, doi:10.1016/0016-7037(93)90036-V, 1993.

Sarmiento, J. L., Gruber, N., Brzezinski, M. A., and Dunne, J. P.: High-latitude controls of thermocline nutrients and low latitude biological productivity, Nature, 427, 56-60, doi:10.1038/nature10605, 2004.

Schmiedl, G. and Mackensen, A.: Multispecies stable isotopes of benthic foraminifers reveal past changes of organic matter decomposition and deepwater oxygenation in the Arabian Sea, Paleoceanography, 21, 1-14, doi:10.1029/2006PA001284, 2006.

Schmittner, A. and Somes, C. J.: Complementary constraints from carbon $\left({ }^{13} \mathrm{C}\right)$ and nitrogen $\left({ }^{15} \mathrm{~N}\right)$ isotopes on the glacial ocean's soft-tissue biological pump, Paleoceanography, 31, 669-693, doi:10.1002/2015PA002905, 2016.

Shackleton, N.: Oxygen Isotope Analyses and Pleistocene Temperatures Re-assessed, Nature, 215, 15-17, doi:10.1038/215015a0, 1967.

Shackleton, N. J.: Carbon-13 in Uvigerina: Tropical rain forest history and the equatorial Pacific carbonate dissolution cycle, in: Andersen, N. R. and Malahoff, A., The Fate of Fossil Fuel in the Oceans, New York (Plenum), 401-427, 1977.
Shemesh, A. A., Macko, S. A., Charles, C. D., and Rau, G. H.: Isotopic Evidence for Reduced Productivity in the Glacial Southern Ocean, Science, 262, 407-410, 1993.

Shibahara, A., Ohkushi, K., Kennett, J. P., and Ikehara, K.: Late Quaternary changes in intermediate water oxygenation and oxygen minimum zone, northern Japan: A benthic foraminiferal perspective, Paleoceanography, 22, 1-13, doi:10.1029/2005PA001234, 2007.

Siddall, M., Rohling, E., Almogi-Labin, A., Hemleben, C., Meischner, D., Schmelzer, I., and Smeed, D. A.: Sea-level fluctuations during the last glacial cycle, Nature, 423, 19-24, doi:10.1038/nature01690, 2003.

Sigman, D. M. and Boyle, E. A.: Glacial/interglacial variations in atmospheric carbon dioxide, Nature, 407, 859-869, 2000.

Sigman, D. M., McCorkle, D. C., and Martin, W. R.: The calcite lysocline as a constraint on glacial/interglacial lowlatitude production changes, Global Biogeochem. Cy., 12, 409, doi:10.1029/98GB01184, 1998.

Sigman, D. M., Hain, M. P., and Haug, G. H.: The polar ocean and glacial cycles in atmospheric $\mathrm{CO}(2)$ concentration, Nature, 466, 47-55, doi:10.1038/nature09149, 2010.

Singh, A. D., Jung, S. J. A., Darling, K., Ganeshram, R., Ivanochko, T., and Kroon, D.: Productivity collapses in the Arabian Sea during glacial cold phases, Paleoceanography, 26, PA3210, doi:10.1029/2009PA001923, 2011.

Skinner, L., McCave, I., Carter, L., Fallon, S., Scrivner, A., and Primeau, F.: Reduced ventilation and enhanced magnitude of the deep Pacific carbon pool during the last glacial period, Earth Planet. Sc. Lett., 411, 45-52, doi:10.1016/j.eps1.2014.11.024, 2015.

Skinner, L. C., Fallon, S., Waelbroeck, C., Michel, E., and Barker, S.: Ventilation of the deep Southern Ocean and deglacial $\mathrm{CO}_{2}$ rise, Science, 328, 1147-1151, doi:10.1126/science.1183627, 2010.

Sowers, T., Bender, M., Raynaud, D., Korotkevich, Y. S., and Orchardo, J.: The $\delta^{18} \mathrm{O}$ of atmospheric $\mathrm{O}_{2}$ from air inclusions in the Vostok Ice Core: Timing of $\mathrm{CO}_{2}$ and ice volume changes during the penultimate deglaciation, Paleoceanography, 6, 679-696, doi:10.1029/91PA02023, 1991.

Stephens, B. B. and Keeling, R. F.: The influence of Antarctic sea ice on glacial-interglacial $\mathrm{CO}_{2}$ variations, Nature, 404, 171-174, doi:10.1038/35004556, 2000.

Stoll, H. M., Klaas, C. M., Probert, I., Encinar, J. R., and Garcia Alonso, J. I.: Calcification rate and temperature effects on $\mathrm{Sr}$ partitioning in coccoliths of multiple species of coccolithophorids in culture, Global Planet. Change, 34, 153-171, doi:10.1016/S0921-8181(02)00112-1, 2002.

Sun, X. and Matsumoto, K.: Effects of sea ice on atmopsheric $p \mathrm{CO}_{2}$ : A revised view and implications for glacial and future climates, J. Geophys Res., 115, 1-9, doi:10.1029/2009JG001023, 2010.

Suthhof, A., Ittekkot, V., and Gaye-Haake, B.: Millenial-scale oscillation of denitrification intensity in the Arabian Sea during late Quaternary and its potential influence on atmospheric $\mathrm{N}_{2} \mathrm{O}$ and global climate, Global Biogeochem. Cy., 15, 637-649, doi:10.1029/2000GB001337, 2001.

Tagliabue, A., Bopp, L., Roche, D. M., Bouttes, N., Dutay, J.-C., Alkama, R., Kageyama, M., Michel, E., and Paillard, D.: Quantifying the roles of ocean circulation and biogeochemistry in gov- 
erning ocean carbon-13 and atmospheric carbon dioxide at the last glacial maximum, Clim. Past, 5, 695-706, doi:10.5194/cp-5695-2009, 2009.

Telesiński, M. M., Spielhagen, R. F., and Bauch, H. A.: Water mass evolution of the Greenland Sea since late glacial times, Clim. Past, 10, 123-136, doi:10.5194/cp-10-123-2014, 2014.

Thomas, E., Booth, L., Maslin, M., and Shackleton, N. J.: Northeastern Atlantic benthic foraminifera and implications of productivity during the last 40,000 years, Paleoceanography, 10, 545562,1995

Thyng, K. M., Greene, C. A., Hetland, R. D., Zimmerle, H. M., and DiMarco, S. F.: Choosing good colormaps, Oceanography, 9, 913, doi:10.5670/oceanog.2016.66, 2016.

van der Weijden, C. H., Reichart, G.-J., and van Os, B. J.: Sedimentary trace element records over the last $200 \mathrm{kyr}$ from within and below the northern Arabian Sea oxygen minimum zone, Mar. Geol., 231, 69-88, doi:10.1016/j.margeo.2006.05.013, 2006.

van Geen, A., Zheng, Y., Bernard, J. M., Cannariato, K. G., Carriquiry, J., Dean, W. E., Eakins, B. W., Ortiz, J. D., and Pike, J.: On the preservation of laminated sediments along the western margin of North America, Paleoceanography, 18, 1098, doi:10.1029/2003PA000911, 2003.

Waelbroeck, C., Paul, A., Kucera, M., Rosell-Melé, A., Weinelt, M., Schneider, R., Mix, A. C., Abelmann, A., Armand, L., Bard, E., Barker, S., Barrows, T. T., Benway, H., Cacho, I., Chen, M.T., Cortijo, E., Crosta, X., de Vernal, A., Dokken, T., Duprat, J., Elderfield, H., Eynaud, F., Gersonde, R., Hayes, A., Henry, M., Hillaire-Marcel, C., Huang, C.-C., Jansen, E., Juggins, S., Kallel, N., Kiefer, T., Kienast, M., Labeyrie, L., Leclaire, H., Londeix, L., Mangin, S., Matthiessen, J., Marret, F., Meland, M., Morey, A. E., Mulitza, S., Pflaumann, U., Pisias, N. G., Radi, T., Rochon, A., Rohling, E. J., Sbaffi, L., Schäfer-Neth, C., Solignac, S., Spero, H., Tachikawa, K., and Turon, J.-L.: Constraints on the magnitude and patterns of ocean cooling at the Last Glacial Maximum, Nat. Geosci., 2, 127-132, doi:10.1038/ngeo411, 2009.
Watson, A. J. and Naveira Garabato, A. C.: The role of Southern Ocean mixing and upwelling in glacial-interglacial atmospheric $\mathrm{CO}_{2}$ change, Tellus B, 58, 73-87, doi:10.1111/j.16000889.2005.00167.x, 2006.

Weber, S. L., Drijfhout, S. S., Abe-Ouchi, A., Crucifix, M., Eby, M., Ganopolski, A., Murakami, S., Otto-Bliesner, B., and Peltier, W. R.: The modern and glacial overturning circulation in the Atlantic ocean in PMIP coupled model simulations, Clim. Past, 3, 51-64, doi:10.5194/cp-3-51-2007, 2007.

Wilson, D. J., Piotrowski, A. M., Galy, A., and Banakar, V. K.: Interhemispheric controls on deep ocean circulation and carbon chemistry during the last two glacial cycles, Paleoceanography, 30, 621-641, doi:10.1002/2014PA002707, 2015.

Xiao, W., Esper, O., and Gersonde, R.: Last Glacial Holocene climate variability in the Atlantic sector of the Southern Ocean, Quaternary Sci. Rev., 135, 115-137, doi:10.1016/j.quascirev.2016.01.023, 2016.

Yokoyama, Y., Webster, J. M., Cotterill, C., Braga, J. C., Jovane, L., Mills, H., Morgan, S., Suzuki, A., and the IODP Expedition 325 Scientists: IODP Expedition 325: Great Barrier Reefs Reveals Past Sea-Level, Climate and Environmental Changes Since the Last Ice Age, Sci. Dril., 12, 32-45, doi:10.2204/iodp.sd.12.04.2011, 2011.

Yu, J., Anderson, R. F., and Rohling, E. J.: Deep ocean carbonate chemistry and glacial-interglacial atmospheric $\mathrm{CO}_{2}$ changes, Oceanography, 27, 16-25, 2014. 